\title{
EFEITO DE ADJUVANTES, VOLUME DE CALDA E QUALIDADE DA ÁGUA NA EFICÁCIA DO HERBICIDA GLYPHOSATE
}

\author{
PERCY ANTONIO GERARDO SALAS PINO
}

Engenheiro Agrônomo

Orientador: Prof. Dr. PEDRO JACOB CHRISTOFFOLETI

Dissertação apresentada à Escola Superior de Agricultura "Luiz de Queiroz", da Universidade de São Paulo, para obtenção do título de Mestre em Agronomia, Área de Concentração: Fitotecnia.

PIRACICABA

Estado de São Paulo - Brasil

Junho de 1996 


\section{Dados Internacionais de Catalogação na Publicação (CIP) \\ DIVISÃO DE BIBLIOTECA E DOCUMENTAÇĀO - Campus “Luiz de Queiroz"/USP}

Salas Pino, Percy Antonio Gerardo

Efeito de adjuvantes, volume de calda e qualidade da água na eficácia do herbicida G/yphosate / Percy Antonio Gerardo Salas Pino. - Piracicaba, 1996.

79p. : il.

Dissertaçāo (mestrado) - Escola Superior de Agricultura Luiz de Queiroz, 1996.

Bibliografia.

1. Herbicida - Experimento 2. Planta daninha - Controle I. Titulo 


\title{
EFEITO DE ADJUVANTES, VOLUME DE CALDA E QUALIDADE DA ÁGUA NA EFICÁCIA DO HERBICIDA GLYPHOSATE
}

\author{
PERCY ANTONIO GERARDO SALAS PINO
}

Aprovada em: 27/08/96

Comissão Julgadora:

Prof. Dr. PEDRO JACOB CHRISTOFFOLETI

Prof. Dr. RICARDO VICTORIA FILHO

Dr. ROBERT DEUBER

ESALQ/USP

ESALQ/USP

IAC

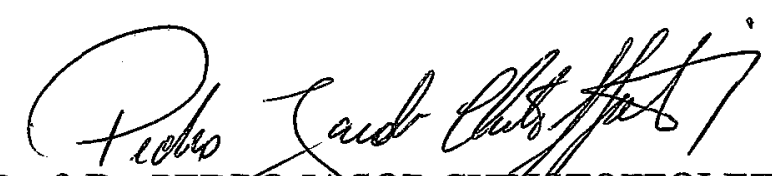

Prof. Dr. PEDRO JACOB CHRTSTOFFOLETI

Orientador 
$A$ minha esposa

SELVA MAYEREGGER DE SALAS

A nossos filhos:

JULIO RAMON

PERCY ANTONIO

MARIO CÉSAR

com muito amor

DEDICO 
A DEUS

por sua grandeza

$e$ infinita bondade.

A meus queridos pais:

JULIO A. SALAS RODRÍGUEZ

REBECA PINO DE SALAS

A meus sogros

RAMÓN MAYEREGGER

MARIA S. PRIETO DE MAYEREGGER

OFEREÇO. 


\section{AGRADECIMENTOS}

Desejo expressar minha profunda gratidão e sincero agradecimento às seguintes pessoas e instituições, que tornaram possível a realização do presente trabalho:

Ao Prof. Dr. Pedro Jacob Christoffoleti, do Departamento de Horticultura da ESALQ/USP, pela orientação, profissionalismo, amizade e apoio na realização da pesquisa.

Ao Prof. Dr. Célio S. Moreira, do Departamento de Horticultura da ESALQ/USP, pela amizade, apoio e orientação durante a formação acadêmica.

A Universidade Nacional de Asunción (UNA) e a Universidade Nacional del Este (UNE) pela permissão para a realização do Curso de Mestrado.

Ao Prof. Eng. Agr. Pedro Gerardo González G., Decano da Facultad de Ciencias Agrarias / UNA, pela oportunidade concedida.

Ao Prof. Eng. Agr. Gerónimo Laviosa G., Decano da Facultad de Engeniería Agronómica / UNE, pela oportunidade concedida.

À Coordenação de Apoio à Pesquisa e Ensino Superior (CAPES), Programa de Estudantes Convênio Pós-Graduação para Estrangeiros (PEC-PG) pela concessão da Bolsa para a realização do Mestrado.

Aos professores do Departamento de Horticultura da ESALQ/USP, Dr. Salim Simão, Dr. Ricardo Victoria Filho, Dr. Keigo Minami, Dr. João Tessarioli Neto, Dr. João Alexio Scarpare Filho, pelos ensinamentos e amizade dispensada. 
As secretárias e funcionários do Departamento de Horticultura da ESALQ/USP, nas pessoas de Luis Ferrari, Aparecido Mendez, Ony R. de Campos, Aparecido Donizete, Antonio Rodrigues e Francisco Rossatte, pela amizade, auxílio e facilidades oferecidas na realização deste e outros trabalhos.

Ao Prof. Dr. Quirino Augusto de Camargo Carmello e à funcionária Lúcia Helena S. Pavan Forti, do setor de Nutrição Mineral de Plantas do Departamento de Química, pela colaboração prestada.

A Bibliotecária Kátia Maria de Andrade Ferraz, pelo auxilio na correção das referências bibliográficas.

Aos colegas da Pós-graduação em Fitotecnia ESALQ/USP, em especial aos da turma de Horticultura, pela amizade e por fazer minha estadia mais prazerosa.

E a todos que direta ou indiretamente, contribuíram para a realização deste trabalho. 


\section{CONTEÚdOO}

Página

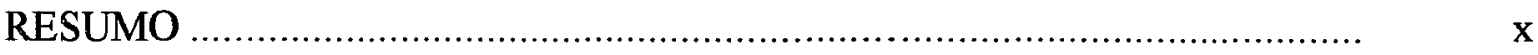

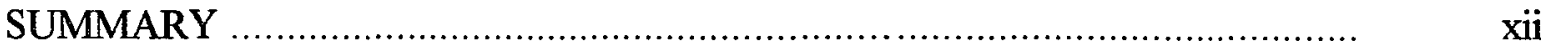

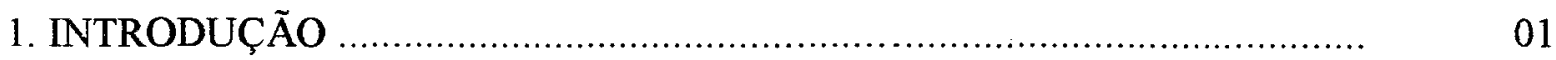

2. REVISÃO DE LITERATURA .................................................... 03

2.1. Eficácia do glyphosate ....................................................... 04

2.2. Efeito dos surfactantes na eficácia do glyphosate ........................... 10

2.3. Efeito de fertilizantes químicos e outras substâncias adjuvantes na eficácia

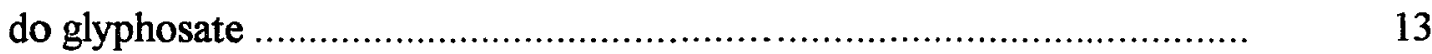

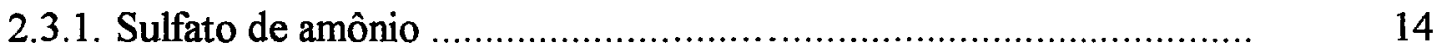

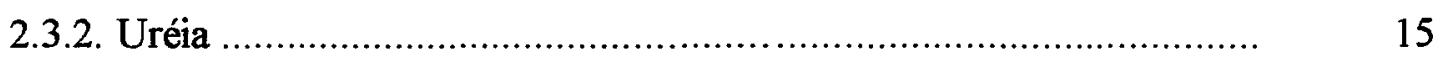

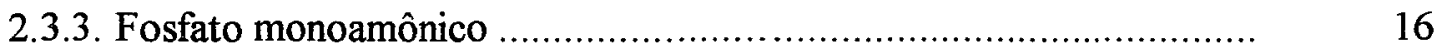

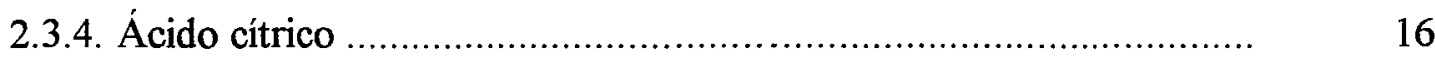

2.4. Efeito da qualidade e volume da água na eficácia do glyphosate ............ . 17

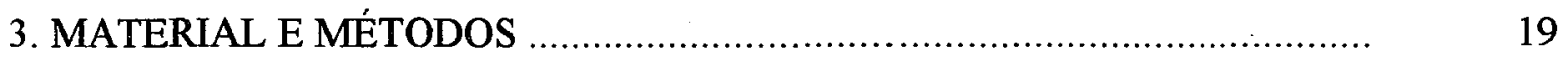

3.1. Efeito dos adjuvantes na eficácia do glyphosate ................................... 19

3.1.1. Local ........................................................................... 19

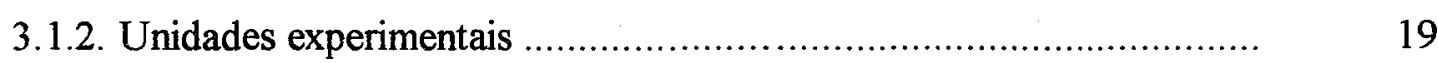

3.1.3. Delineamento experimental e tratamentos .............................. 20

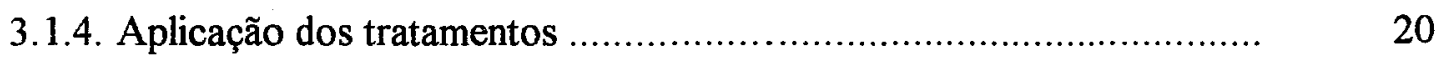

3.1.5. Avaliação do experimento ............................................ 22

3.1.6. Análise estatística ....................................................... 22 
Página

3.2. Efeito do volume de calda, doses e adjuvantes na eficácia do glyphosate ...

3.2.1. Local

3.2.2. Unidades experimentais

3.2.3. Delineamento experimental e tratamentos

3.2.4. Aplicação dos tratamentos ..................................................... 25

3.2.5. Avaliação do experimento ................................................... 25

3.2.6. Análise estatística .................................................. 26

3.3. Efeito dos sais e dos adjuvantes na eficácia do glyphosate ........................ 26

3.3.1. Local ............................................................................. 26

3.3.2. Unidades experimentais ......................................... 26

3.3.3. Delineamento experimental e tratamentos .............................. 27

3.3.4. Aplicação dos tratamentos ........................................................ 27

3.3.5. Avaliação do experimento ................................................... 29

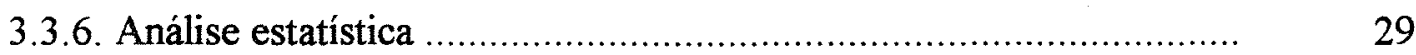

3.4. Efeito da qualidade da água de diferentes fontes e dos adjuvantes na eficácia do glyphosate

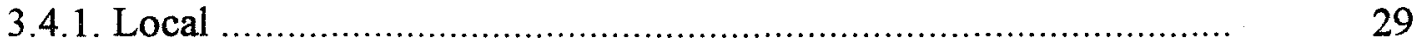

3.4.2. Unidades experimentais .............................................. $\quad 30$

3.4.3. Delineamento experimental e tratamentos ................................. 30

3.4.4. Aplicação dos tratamentos ....................................................... 32

3.4.5. Avaliação do experimento ...............................................

3.4.6. Análise estatística ............................................................ 35

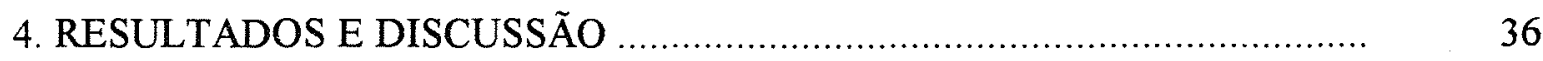

4.1. Efeito dos adjuvantes na eficácia do glyphosate ................................ 36

4.2. Efeito do volume de calda, doses e adjuvantes na eficácia do glyphosate .... 52

4.2.1. Efeito da interação do volume de calda com doses de glyphosate .... 52

4.2.2. Efeito da interação de adjuvantes com doses de glyphosate no controle de C. rotundus 
Página

4.2.3. Efeito da interação de adjuvantes com o volume de calda, no controle de C. rotundus

4.3. Efeito dos sais e dos adjuvantes na eficácia do glyphosate 58

4.4. Efeito da qualidade da água de diferentes fontes e dos adjuvantes na eficácia do glyphosate

5. CONCLUSÕES 


\title{
EFEITO DE ADJUVANTES, VOLUME DE CALDA E QUALIDADE DA ÁGUA NA EFICÁCIA DO HERBICIDA GLYPHOSATE
}

\author{
Autor: PERCY ANTONIO GERARDO SALAS PINO
}

Orientador: Prof. Dr. PEDRO JACOB CHRISTOFFOLETI

\section{RESUMO}

No presente trabalho foram conduzidos quatro experimentos para avaliar os efeitos de adjuvantes, volumes de calda, qualidade das águas de diferentes fontes e concentração de sais, na eficácia do herbicida glyphosate. Os adjuvantes testados foram sulfato de amônio, fosfato monoamônico, uréia e surfactante (mistura de isooctil fenóxi polietóxi etanol e dioctil sulfonato de sódio). Os ensaios foram realizados nas instalações do Departamento de Horticultura da Escola Superior de Agricultura "Luiz de Queiroz", Universidade de São Paulo, Piracicaba-SP, Brasil. Os experimentos sobre o efeito dos adjuvantes e volumes da água, foram conduzidos em casa-de-vegetação, usando como planta teste a tiririca (Cyperus rotundus $\mathrm{L}$.), sendo que os experimentos sobre o efeito dos sais e fontes de água foram conduzidas em ambiente não protegido, usando sorgo granífero (Sorghum bicolor L.). Verificou-se que o sulfato de amônio $(2 \% \mathrm{p} / \mathrm{v})$ aumentou significativamente o controle da planta aos 75 dias após a aplicação do herbicida, sendo 
possível reduzir a dose de $1,44 \mathrm{~kg}$ e.a./ha pela metade com a mesma eficácia. A uréia $(2,00 \% \mathrm{p} / \mathrm{v})$ também foi muito eficiente e permitiu reduzir a dose maior de glyphosate pela metade, sem perder a eficácia. Entretanto, o fosfato monoamônico não causou aumentos significativos e o surfactante reduziu a eficácia, sobretudo das doses mais baixas do herbicida. A redução do volume da calda de 300 para 150 1/ha aumentou a eficácia da dose mais baixa do glyphosate $(0,36 \mathrm{~kg}$ e.a./ha). Os sais de cloreto de cálcio, cloreto de magnésio, bicarbonato de sódio, sulfato ferroso e sulfato de zinco reduziram significativamente a eficácia do glyphosate. $\mathrm{O}$ sulfato de amônio e o fosfato monoamônico superaram o efeito antagônico dos sais, com exceção do sulfato ferroso. Das fontes de água testadas, somente a água subterrânea diminuiu significativamente a eficácia do glyphosate, devido a alta concentração de sais, especialmente de cálcio e sódio. 


\section{ADJUVANTS, SPRAY VOLUME AND WATER QUALITY EFFECTS ON GLYPHOSATE HERBICIDE EFFICACY}

Author: PERCY ANTONIO GERARDO SALAS PINO

Adviser: Prof. Dr. PEDRO JACOB CHRISTOFFOLETI

\section{SUMMARY}

This research was carried out by four experiments in order to evaluate the effects of adjuvants, volume and source of water used in the spray dilution and salt concentration on glyphosate herbicide efficacy. The tested adjuvants were ammonium sulfate, monoamonic phosphate, urea and surfactant (mixture of ethanol polietoxy phenoxy isooctyl and sodium solfonate dioctyl). The experiments were conducted at the Department of Horticulture facilities of Escola Superior de Agricultura "Luiz de Queiroz", Universidade de São Paulo, Piracicaba - SP, Brazil. The assays, about the adjuvant effects and spray volume effects, were conducted in a greenhouse, with the weed Cyperus rotundus $\mathrm{L}$., and the experiments salt effects and water sources were conducted outside under natural conditions, using sorghum. It was observed that ammonium sulfate $(2 \% \mathrm{w} / \mathrm{v})$ increased significantly the weed control by glyphosate 75 days after application (DAA), allowing a rate reduction to half of the higher rate $(1.44 \mathrm{~kg}$ a.e. $/ \mathrm{ha})$, with the same efficacy. Urea $(2.00 \%$ 
w/v) was also very efficient and allowed a rate reduction of the higher dosage $(1.44 \mathrm{~kg}$ e.a./ha) to half, keeping the efficacy. However, the monoamonic phosphate did not increase glyphosate efficacy significantly, and the surfactant reduced the efficacy, specially at lower herbicide rates. The spray volume reduction from 300 to $1501 /$ ha increased the efficacy of the lower glyphosate rate $(0.36 \mathrm{~kg}$ a.e./ha). The salts sodium chloride, magnesium chloride, sodium bicarbonate, iron sulfate and zinc sulfate reduced significantly glyphosate efficacy. The ammonium sulfate and monoamonic phosphate did not allow the antagonic salt effects, except for iron sulfate. From the water sources tested only one underground water reduced significantly glyphosate efficacy due to high salt concentration, specially calcium and sodium salts. 


\section{INTRODUÇÃO}

O glyphosate é um herbicida sistêmico de ação total que vem sendo usado com muito sucesso, no mundo, desde a década de setenta no controle das plantas daninhas anuais e perenes. Sua importância cresce na atualidade com o surgimento de cultivares transgênicos resistentes a este herbicida nas culturas de soja, algodão, tomate, beterraba, linho e tulipa.

No Brasil é amplamente usado nas culturas de citros, bananeira, videira, macieira, café, reflorestamento e no plantio direto de culturas anuais como soja, trigo, milho e outras. Conseqüentemente, é um herbicida aplicado em larga escala na agricultura brasileira.

As doses usadas pelos agricultores normalmente superam as recomendadas, justificando-as pelos melhores resultados obtidos. Na realidade é bem provável que outros fatores estejam contribuindo nessa menor eficiência do glyphosate, pressionando as doses a serem elevadas. Um desses fatores pode ser o conteúdo de sais na água usada na calda e que são antagônicos à ação do glyphosate. O volume de água usada na aplicação pode também influir na eficácia deste herbicida. 
Os adjuvantes estão sendo usados para aumentar a eficácia de muitos herbicidas e conseguir a redução das doses e outros benefícios econômicos, ambientais e toxicológicos.

Os conhecimentos sobre o modo de ação dos diversos tipos de adjuvantes não estão bem esclarecidos, motivo pelo qual não se podem fazer predições sobre os resultados de seu desempenho com um determinado herbicida, nas espécies alvo consideradas. Em conseqüência, a seleção do adjuvante ainda deve-se realizar com base em testes de eficiência ou "screenings".

Assim, no presente trabalho, foram conduzidos quatro experimentos com o objetivo de avaliar: o efeito dos adjuvantes, sulfato de amônio, fosfato monoamônico, uréia e surfactante AF (mistura de isooctil fenóxi poli etóxi etanol e dioctil sulfonato de sódio); a interação das doses do glyphosate com volumes da calda e adjuvantes, assim como, o efeito dos sais (cloreto de cálcio, cloreto de magnésio, bicarbonato de sódio, sulfato ferroso e sulfato de zinco) e suas interações com os adjuvantes e o efeito das fontes da água, na eficácia do glyphosate. 


\section{REVISÃO DE LITERATURA}

O glyphosate é herbicida aplicado em condições de pós-emergência, de ação total, não seletivo às culturas, registrado no Brasil, para o uso em jato dirigido às entrelinhas das culturas de citros, cacau, café, seringueira, bananeira, pomares de frutíferas, pinus, eucalipto; utilizado no "manejo" do sistema de plantio direto (aplicado antes da semeadura) nas culturas de soja, milho, trigo e arroz; usado na eliminação de pastagens e canaviais; no controle da vegetação em áreas não cultivadas e também no controle de plantas daninhas em ambientes aquáticos (RODRIGUES \& ALMEIDA, 1995).

O glyphosate [N-(fosfonometil)glicina] na forma de sal isopropil amina é altamente solúvel, movimenta-se na planta pelo apoplasto e simplasto; sua translocação é extensiva, pelo floema, atingindo os meristemas da parte aérea das plantas e das estruturas vegetativas de sub-superficie. Seu principal modo de ação é inibir a síntese dos aminoácidos aromáticos, fenilalanina, tirosina e triptofano, e consequentemente a interrupção da síntese de proteínas, compostos fenólicos e clorofila, inibindo o crescimento (COLE, 1985). 
As doses de aplicação recomendadas para o controle das plantas daninhas, tanto anuais quanto perenes, variam entre 0,36 a $2,16 \mathrm{~kg} / \mathrm{ha}$ de equivalente ácido (e.a.); as doses maiores são recomendadas para plantas em estádio de desenvolvimento mais adiantado ou espécies de mais dificil controle (RODRIGUES \& ALMEIDA, 1995).

\subsection{Eficácia do glyphosate}

A eficácia dos herbicidas sistêmicos depende da absorção e transiocação das moléculas do herbicida até o local de ação, na concentração adequada para provocar a morte da planta (VICTORIA FILHO, 1985).

A primeira barreira para a absorção do glyphosate é a cutícula, que recobre toda a parte aérea das plantas e protege-a das perdas de água e solutos, impedindo o ingresso de patógenos e outras substâncias depositadas na superficie. Mesmo assim, é permeável a alguns agroquímicos, gases e até a água (MARTIN \& JUNIPER, 1970; HOLLOWAY, 1993).

CASELEY \& COUPLAND (1985) referem que o glyphosate, devido a polaridade da molécula e conseqüente solubilidade em água, penetra no simplasto por difusão, atravessando a cutícula pela via hidrofilica. Acredita-se que a cutina e as fibras de carbohidratos promovem uma rota polar entre a porção cerosa não polar da cutícula e quando a planta possui boa disponibilidade de água, a porção polar se hidrata e dilata, permitindo maior difusão do glyphosate. 
A penetração cuticular do glyphosate em Phaseolus vulgaris L. foi rápida, mas seguida por uma fase lenta de absorção pelas células do mesófilo (BRECKE \& DUKE, 1980).

Muitos pesquisadores sugerem que a mebrana celular é uma barreira que limita a absorção foliar do glyphosate. HADERLIE et al. (1977) encontraram que menos de $1 \%$ do glyphosate do meio extracelular foi absorvido pelas células de cenouras cultivadas em suspensão depois de 96 horas. RICHARD \& SLIFE (1979), determinaram que a absorção celular pode oferecer maior resistência à absorção do glyphosate que a penetração cuticular. Eles sugeriram que o potencial negativo da membrana celular repele a molécula aniônica do glyphosate. WYRILL \& BURNSIDE (1976), relataram que a remoção da cera da superficie da cutícula de Asclepias syriaca L. e de Apocynum cannabinum L. não aumentou a absorção do glyphosate. RIECHERS et al. (1994), compararam a absorção do glyphosate com o aminoácido glutamato, assinalando que o glyphosate não usou o transportador de aminoácido para entrar nas células das folhas, e que a membrana celular parece ser uma importante barreira para a absorção do glyphosate. Além disso, relatam que o fluxo de glyphosate foi muito menor que os de bentazon e atrazine, herbicidas lipídiopermeáveis que difundem-se através da membrana facilmente.

GOUGLER \& GEIGER (1981), estudaram a entrada do glyphosate no mesófilo das células de beterraba açucareira, e concluiram que o glyphosate absorvido depende da concentração e da lenta exodifusão o qual indica um mecanismo passivo.

WADE et al. (1993), relatam que existem consideráveis evidências que indicam que a membrana celular é a barreira para a penetração intracelular dos herbicidas e um dos locais de ação dos adjuvantes. 
A translocação do glyphosate à meristemas dos bulbos, rizomas, raizes e tubérculos responde a uma típica relação de fonte-dreno (SPRANKLER et al., 1975; SANDBERG et al., 1980; McALLISTER \& HADERLIE, 1985).

ZANDSTRA \& NISHIMOTO (1977), verificaram que tubérculos novos de Cyperus rotundus mostraram maior concentração, do glyphosate marcado, que as folhas. O glyphosate parece translocar-se através dos tubérculos maduros até os recém formados e às pontas dos rizomas.

Diversos pesquisadores encontraram um forte paralelismo entre a distribuição dos fotoassimilados e o glyphosate importado pelos drenos (GOUGLER \& GEIGER, 1981; MARTIN \& EDGINTON, 1981; SHIEH et al., 1993; DEVINE \& HALL, 1990). A concentração do glyphosate nos meristemas depende da atividade dos drenos (TARDIF \& LEROUX, 1990; SHIEH et al., 1993).

SHIEH et al. (1993), em Elytrigia repens L., encontraram que a primeira gema da ponta do rizoma acumulou três vezes mais glyphosate que a gema basal. Assim mesmo, a proporção glyphosate/sacarose foi dez vezes maior na primeira gema. Relatam também, que o aumento variável da atividade das gemas, faz com que algumas das mais velhas acumulem só uma pequena quantidade, sub-letal, de glyphosate, o que explicaria a tendência das gemas das regiões mais velhas do rizoma a escapar do controle. Com a morte das gemas mais ativas, as que contém doses sub-letais poderiam sair da dormência.

A absorção, translocação e acumulação do glyphosate nos meristemas é grandemente influenciado pela aplicação, condições do ambiente, tipo e estádio fenológico das plantas, dose aplicada, qualidade da água e adjuvantes. 
A retenção das gotas na superficie das folhas é fundamental para a absorção do herbicida. Segundo, De RUITER et al. (1990), a retenção das gotas foi maior nas espécies com superficie lisa que as com superficie irregular. A cera epicuticular cristalizada mantém ar entre as gotas e a superficie das plantas, aumentando a possibilidade das gotas serem escorridas.

HESS \& FOLK (1990), consideram que o estreito contato do resíduo das gotas com a cutícula é essencial para a difusão do herbicida através da cutícula. A cera epicuticular limita o espalhamento das gotas retidas impedindo o maior contato dos resíduos das gotas com a epiderme. Formulações de herbicidas que secam como sólidos, também limitam o contato com a superficie e dificultam a difusão. $\mathrm{O}$ contato dos resíduos das gotas com a superficie parece estar influenciado pelas espécies, assim como pelos sais na calda.

NALEWAJA et al. (1992), encontraram que os cristais formados pelo sulfato de amônio na superficie das folhas favoreceram o contato do glyphosate com a epiderme e aumentaram sua absorção; no entanto, os depósitos amorfos, densos e sem cristais dos sais de cálcio, misturadas com o glyphosate, limitaram o contato das moléculas do herbicida, diminuindo sua absorção.

Os fatores ambientais, temperatura e umidade relativa (JORDAN, 1977); luz (KELLS \& RIECK, 1979); vento, precipitação pluvial (CASELEY \& COUPLAND, 1985) e umidade do solo (CHASE \& APPLEBY, 1979); exercem um pronunciado efeito direto ou indireto na absorção e translocação do glyphosate.

Os fatores bióticos como, insetos (WESTRA et al., 1981); patógenos (WALLACE \& BELLINDER, 1995) e plantas parasitas (ARJONA-BERRAL et al., 1990), 
que reduzem a fotoassimilação ou desorganizam o floema, como conseqüência reduzem a translocação do glyphosate às gemas.

A absorção e translocação do glyphosate varia com as espécies e com o estádio de desenvolvimento das plantas daninhas. A respeito, TUCKER et al. (1994), relatam que a absorção do glyphosate pela Alternanthera philoxeroides L. a 1, 2, 4 e 8 dias após a aplicação (DAA) foi $19,16,30$ e $42 \%$, respectivamente e a translocação para as gemas axilares foi $2 \%$ e nas raizes $1 \%$, oito DAA. Em Elytrigia repens L., SHIEH et al. (1993) encontraram que a absorção de glyphosate 4 horas após da aplicação, foi $36 \%$, seguida por uma lenta absorção até alcançar o máximo 53\% aos dois DAA. No entanto, TARDIF \& LEROUX (1990) trabalhando com cinco biotipos da mesma espécie (E. repens L.), encontraram $80 \%$ de absorção do glyphosate sete DAA, sendo que a absorção foi similar entre os biotipos.

ZANSDTRA \& NISHIMOTO (1977), relataram que a translocação do glyphosate na tiririca (Cyperus rotundus L.), aumentou de 1\% à um DAA para 19\% aos quatro D.A.A.

PEREIRA \& CRABTREE (1986), verificaram que a absorção e translocação do glyphosate, principalmente nas folhas e tubérculos novos, foi maior quando foi aplicado em plantas jovens de tiriricão (Cyperus esculentus L.) de 30 dias do que nas de 60 dias de idade. Além disso, limitaram a formação de tubérculos e a concentração de glyphosate nas folhas, raízes, rizomas e tubérculos novos das plantas velhas, sendo quase a metade do nível das plantas jovens.

JEFFERY et al. (1981), observaram que o controle do capim massambará (Sorghum halepense L.) foi adequado só quando atingiu $30 \mathrm{~cm}$ de altura; sendo 
que, para Elytrigia repens L., o controle foi satisfatório quando as plantas apresentaram quatro folhas (IVANY, 1975; RIOUX et al., 1974) e para Calamagostris canadensis Michx., depois que as plantas floresceram e produziram sementes (CONN \& DECK, 1991).

CONN \& DECK (1995), obtiveram o melhor controle de Hordeum jubatum L., após o enchimento das sementes, ao contrário, o menor controle foi no momento de máximo dreno nas sementes em enchimento.

DURIGAN (1992), obteve o melhor controle do capim-colonião (Panicum maximum) quando a aplicação do glyphosate foi realizada no início do florescimento e na frutificação, quer seja no seu desenvolvimento inicial ou após a brotação da soqueira, sendo que, o herbicida causou a inviabilização das sementes produzidas.

CAMACHO \& MOSHIER (1991), encontraram que o glyphosate foi mais eficiente no controle de capim-massambará ( $S$. halapense) quando aplicado em plantas jovens com menos de cinco folhas.

ZANDSTRA \& NISHIMOTO (1977), concluíram que o melhor momento para o controle de Cyperus rotundus $\mathrm{L}$. com glyphosate foi quando há máxima produção de tubérculos, recém-formados e conectados por rizomas ainda com tecidos novos. Nas plantas velhas, a translocação diminui consideravelmente devido à entrada em dormência dos tubérculos e à forte dominância apical entre tubérculos e das gemas nos . tubérculos.

Em relação ao efeito das doses na eficácia do glyphosate, DOLL \& PIEDRAHITA (1982), relatam que 1,5 e $2,0 \mathrm{~kg} / \mathrm{ha}$ de glyphosate inibiram a rebrota dos tubérculos originais de $C$. rotundus. A translocação do glyphosate a $1,0 \mathrm{~kg} / \mathrm{ha}$ foi 
completada em 72 horas, enquanto 36 horas foram suficientes com $2,0 \mathrm{~kg} / \mathrm{ha}$. Sugerem os autores, que a resposta dos tubérculos é dependente da dose.

DEUBER \& FORSTER (1977), em Campinas, testaram doses de glyphosate para o controle de tiririca em condições de campo $(0,48 ; 0,96$ e $1,44 \mathrm{~kg}$ i.a./ha) e em casa-de-vegetação $(0,72 ; 1,44$ e $2,16 \mathrm{~kg}$ i.a./ha) e relataram que o controle das manifestações epígeas e do número de tubérculos, foi mais eficiente pelas doses maiores em ambos os ambientes.

BOERBOOM \& WYSE (1988) mostraram que baixas concentrações de glyphosate controlaram melhor Cirsium arvense L. Scap., que as altas concentrações. A concentração alta de glyphosate $(20,4 \mathrm{~kg} / \mathrm{ha})$ reduziu a absorção e translocação de carbono marcado do glyphosate comparado com baixa concentração $(1,7 \mathrm{~kg} / \mathrm{ha})$. As altas concentrações de glyphosate podem causar uma rápida fitotoxicidade do tecido, reduzindo a translocação e fraco controle das plantas daninhas perenes.

\subsection{Efeito dos surfactantes na eficácia do glyphosate}

Numerosas pesquisas evidenciam o efeito dos surfactantes no aumento da eficácia do glyphosate (WYRILL \& BURNSIDE, 1977; O'SULLIVAN et al., 1981; JORDAN, 1981; GASKIN \& HOLLOWAY, 1992; RIECHERS et al., 1995).

De RUTTER et al. (1990) relatam que os diversos tipos de surfactantes não possuem a mesma capacidade para aumentar a penetração e a fitotoxicidade do glyphosate. Observaram que a absorção de glyphosate aumentou com o 
uso do surfactante catiônico Ethomeen T/25 e diminuiu com o surfactante aniônico Renex 688.

Os surfactantes catiônicos polioxietileno amino terciários foram mais eficazes que os aniônicos em promover a fitotoxicidade do glyphosate (WYRILL \& BURNSIDE, 1977; SHERRICK et al., 1986; RIECHERS et al., 1995).

A absorção de herbicidas lipofilicos são favorecidos pela adição de surfactantes não iônicos com baixo conteúdo de oxietileno (5-6 unidades de $\mathrm{OE}$ ), os quais são bons espalhantes. No entanto, surfactantes com alto conteúdo de oxietileno (15-20 unidades de OE) com pequena capacidade espalhante, são os melhores ativadores da absorção dos herbicidas hidrofilicos (GASKIN \& HOLLOWAY, 1992).

RIECHERS et al. (1995), encontraram que os surfactantes catiônicos aumentaram consideravelmente a eficácia do glyphosate. A eficiência varia com o conteúdo de etoxilados (OE), as aminas alifáticas terciárias com 10 unidades de $\mathrm{OE}$ foram as mais ativas, superando as aminas alifáticas quaternárias. Os surfactantes não iônicos não aumentaram o efeito do glyphosate.

GREN \& GREN (1993), encontraram que os surfactantes aniônicos com estrutura e concentração adequada $(0,05-0,10 \%)$, incrementaram 10 vezes a atividade do rimsulfuron. Afirmam que o balanço hidrofilico-lipofilico (BHL) do surfactante e a forma fisica da gota depositada na folha explicam a influência na atividade biológica do herbicida. Os surfactantes mais ativos possuem BHL de 12 a 17 e formam um gel quando depositado na forma de gota sobre as folhas.

Os surfactantes podem incrementar a penetração foliar de diversas maneiras. Melhoram o contato da solução do herbicida com a folha, melhorando a 
molhabilidade (GASKIN \& HOLLOWAY, 1992), podem inibir a cristalização dos ingredientes ativos na superficie da cutícula, mantendo assim o composto num estado fisicoquímico mais disponível (MaciSAAC et al., 1991) e também tem sido proposto que podem modificar as interações entre a cutícula e o ingrediente ativo (BUKOVAC et al., 1990). Aumentam a hidratação da cutícula, melhorando a rota aquosa de difusão do glyphosate (CORET \& CHAMEL, 1993).

SHERRICK et al. (1986), assinalam que os surfactantes para promover maior fitotoxicidade do glyphosate, são requeridos em concentrações maiores que as necessárias para reduzir a tensão superficial, indicando que o modo de ação não está só limitado à sua ação como espalhante das gotas, mas poderiam estar envolvidos no aumento da permeabilidade da cutícula ou da membrana celular ou de ambas.

STOCK \& HOLLOWAY (1993), referem que os surfactantes, além de melhorarem a deposição e retenção do herbicida, podem penetrar na cutícula, as vezes rapidamente, para atingir outros lugares de ação como a membrana celular, aumentando sua permeabilidade a baixas concentrações ou danificando-a a maiores concentrações.

RIECHERS et al. (1994), observaram que a eficácia dos surfactantes para incrementar a absorção do glyphosate, depende da habilidade de se difundir através da cutícula para chegar no apoplasto, e atuar diretamente na membrana celular com a proteína ou com os lipídios, aumentando sua permeabilidade.

Segundo KIRKWOOD (1993), os surfactantes podem atuar como "modificadores da pulverização"; quando melhoram a umectância e o espalhamento das aplicações, sendo muito usados em herbicidas de pós-emergência, que necessitam uma 
aplicação uniforme na folhagem para o máximo efeito. Os surfactantes "ativadores", no entanto, são usados especificamente para incrementar a absorção foliar dos herbicidas sistêmicos e melhorar sua atividade biológica. Os ativadores incluem condensados de polioxietilenos (álcoois, alquilfenois, alquilaminas) com balanço hidrofilico-lipofilico (BHL) de 10 a 13 .

O efeito dos surfactantes na ativação da absorção do glyphosate depende da composição química, da concentração dos surfactantes e das interações desses compostos com o herbicida e as espécies-alvo (STOCK \& HOLLOWAY, 1993; KNOCHE \& BUKOVAC, 1993; RIECHERS et al., 1995).

Vários fatores chaves tem sido identificados no processo de ativação da absorção, os quais podem ter lugar nas gotas, no depósito formado na superficie das folhas, na cutícula antes ou durante a penetração, sob os tecidos do local de aplicação ou na membrana celular. Os detalhes precisos dos seus mecanismos de ação, no entanto, ainda não foram bem esclarecidos (STOCK \& HOLLOWAY, 1993).

\subsection{Efeito de fertilizantes químicos e outras substâncias adjuvantes na eficácia do glyphosate}

A ação dos fertilizantes no aumento da atividade do glyphosate ainda não está bem esclarecida; provavelmente os fertilizantes e outras substâncias como adjuvantes, atuem prevenindo a formação de sais complexos do glyphosate com os sais 
contidos na calda; ou pela ação do ion amônio, ao aumentar o potencial da membrana celular (NALEWAJA, 1995).

\subsubsection{Sulfato de amônio}

A adição de sulfato de amônio à calda de aplicação aumentou a eficácia dos herbicidas: DNOC (Harris \& Hyslop, 1942 citado por GRONWALD et al., 1993), picloram (WILSON \& NISHIMOTO, 1975), dichlorprop (TURNER \& LOADER, 1984), imazethapyr (KENT et al., 1991), sethoxydim (YORK et al., 1990; HARKER, 1992; NALEWAJA et al., 1994) e clethodim (HARKER, 1995).

No glyphosate, a ação deste adjuvante é também de aumento da eficiência. SUWUNNAMEK \& PARKER (1975), relatam que o sulfato de amônio aumentou significativamente a atividade do glyphosate em tiririca (Cyperus rotundus $\mathrm{L}$.), ainda na estação seca. TURNER \& LOADER (1980), observaram que o sulfato de amônio isolado ou em mistura com o surfactante Ethomeen $\mathrm{C12}$, aumentaram o efeito do glyphosate no controle de Agropyron repens L. Os melhores resultados foram obtidos com concentrações de sulfato de amônio de 1 a $10 \%$ p/v; concentrações maiores tiveram efeito antagônico.

GUTMARÃES (1981), relata que $5 \mathrm{~kg} / \mathrm{ha}$ de sulfato de amônio adicionado a calda de glyphosate aumentou o nível de controle da tiririca (C. rotundus $\mathrm{L}$.) em condições de campo. DONALD (1988), encontrou excelente controle de Hordeum jubatum L. com $0,56 \mathrm{~kg}$ e.a./ha de glyphosate mais $2,8-5,6 \mathrm{~kg} / \mathrm{ha}$ de sulfato de amônio. 
SALISBURY et al. (1991), relatam que o sulfato de amônio aumentou a eficácia do glyphosate no controle de capim-massambará (Sorghum halepense L.). A adição de $3,3 \mathrm{~kg} / \mathrm{ha}$ de sulfato permitiu a redução da dose de glyphosate de 0,84 $\mathrm{kg} / \mathrm{ha}$ para $0,42 \mathrm{~kg} / \mathrm{ha}$, com a mesma eficiência.

PAVEZI (1988), relata que o sulfato de amônio ( $2 \%$ p/v) não incrementou a ação do glyphosate $(1,44 \mathrm{~kg} / \mathrm{ha})$ no controle da tiririca (C. rotundus $\mathrm{L}$.).

NALEWAJA \& MATYSIAK (1992a) observaram que o efeito do sulfato de amônio na ação do glyphosate depende da espécie alvo. Em girassol, aumentou fortemente a toxicidade do glyphosate; no entanto, em soja e Kochia scoparia, o efeito foi antagônico.

A adição de sulfato de amônio aumentou a eficácia das doses baixas de sethoxydim em condições ambientais ótimas para a atuação do referido herbicida, ou das doses normalmente recomendadas, em condições não ótimas (HARKER \& O'SULLIVAN, 1988).

\subsubsection{Uréia}

A uréia aumentou a eficácia do glyphosate no controle da tiririca $(C$. rotundus); o efeito foi quase igual ao encontrado com sulfato de amônio. Uréia a $10 \mathrm{~kg} / \mathrm{ha}$ foi mais eficiente que $2,45 \mathrm{~kg} / \mathrm{ha}$ (SUWUNNAMEK \& PARKER, 1975).

PUREA (1986), reportou que a adição de 5 g/l de uréia permitiu a redução da dose de glyphosate de 10 para $6 \mathrm{ml} / 1$, sem perder a eficácia no controle de C. rotundus. 
GUIMARÃES (1981), relatou que uréia $(2,6 \mathrm{~kg} / \mathrm{ha})$ incrementou o efeito do glyphosate no controle da tiririca (C. rotundus $\mathrm{L}$.), em condições de campo e laboratório.

DURIGAN (1992), observou que a adição de $0,2 \%$ de uréia na calda de aplicação permitiu redução de 1,80 para $1,44 \mathrm{~kg} / \mathrm{ha}$ do e.a. do glyphosate, sem prejuizos para o controle de capim-colonião (Panicum maximum).

\subsubsection{Fosfato monoamônico}

O fosfato monoamônico aumentou a absorção do picloram (WILSON \& NISHIMOTO, 1975); aumentou também a eficácia do glyphosate (aplicado a 0,5 kg/ha) no controle de tiririca (C. rotundus $\mathrm{L}$.), alcançando níveis de controle semelhantes aos encontrados com a adição de sulfato de amônio ou uréia (SUWUNNAMEK \& PARKER, 1975).

\subsection{4. Ácido cítrico}

O ácido cítrico aumentou a fitotoxicidade do glyphosate, superando o efeito antagônico que o bicarbonato de sódio, cloreto de cálcio e sulfato férrico exercem sobre este herbicida (NALEWAJA \& MATYSIAK, 1991).

THELEN et al. (1995b), relatam que o ácido cítrico superou o antagonismo do cálcio sobre a eficácia do glyphosate, quando foram usadas concentrações molares duas ou quatro vezes maiores que as do cálcio. 


\subsection{Qualidade da água: sais e volume na eficácia do glyphosate}

A água usada na calda de aplicação contém, naturalmente, uma quantidade variável de sais, os quais tem um efeito antagônico diferenciado na fitotoxicidade do glyphosate (STAHLMAN \& PHILLIPS, 1979; O'SULLIVAN et al., 1981; BUHLER \& BURNSIDE, 1983; NALEWAJA \& MATYSIAK, 1991).

STAHLMAN \& PHILLIPS (1979), encontraram que os íons de ferro e aluminio são os que têm maior efeito antagônico na fitotoxicidade do glyphosate, seguidos, em ordem decrescente, pelo zinco, cálcio e magnésio. $\mathrm{O}$ potássio e sódio não reduziram o efeito do glyphosate. No entanto, BUHLER \& BURNSIDE (1983) e SHEA \& TUPY (1984) relataram que o bicarbonato e carbonato de sódio foram antagônicos ao glyphosate.

NALEWAJA \& MATYSIAK (1991), determinaram a influência de vários cátions sobre a fitotoxicidade do glyphosate e encontraram que a intensidade do antagonismo foi a seguinte: ferro $>$ zinco $>$ cálcio $\geq$ magnésio $>$ sódio $>$ potássio.

SANDBERG et al. (1978) relataram que o cálcio reduziu a atividade do glyphosate e que a inibição foi relacionada ao volume da calda usada; com maior volume, o glyphosate foi mais sensível ao cálcio.

O antagonismo dos sais tem sido superado, aumentando a dose do ingrediente ativo ou diminuindo o volume da calda (STAHLMAN \& PHILLIPS, 1979; O’SULLIVAN et al., 1981; BUHLER \& BURNSIDE, 1983). 
Reduzir o volume da calda poderia ser o método mais fácil de incrementar a eficácia do glyphosate, já que não só diminui a quantidade dos cátions ligados com as moléculas de glyphosate, mas também incrementa a concentração de glyphosate nas gotas (O'SULLIVAN et al., 1981; AMBACH \& ASHFORD, 1982; BUHLER \& BURNSIDE, 1983). No entanto, uma redução significativa no volume da calda pode diminuir a eficiência da aplicação, e consequentemente, a eficácia do herbicida.

O uso de surfactantes, sulfato de amônio, fosfato monoamônico, ácido cítrico e outras substâncias adjuvantes são alternativas viáveis para superar o antagonismo dos cátions da calda e aumentar a eficácia do glyphosate (SHEA \& TUPY, 1984; NALEWAJA \& MATYSIAK, 1991; NALEWAJA \& MATYSIAK, 1992b; NALEWAJA \& MATYSIAK, 1993, NALEWAJA et al., 1994; HARKER, 1995; THELEN et al., 1995b). 


\section{MATERIAL E MÉTODOS}

Quatro experimentos foram conduzidos nas instalações do Departamento de Horticultura da Escola Superior de Agricultura "Luiz de Queiroz", Universidade de São Paulo, Piracicaba, SP, Brasil.

\subsection{Efeito de adjuvantes na eficácia do glyphosate}

\subsubsection{Local}

O experimento foi conduzido em casa-de-vegetação. A temperatura média durante a condução do experimento foi mantida em $30^{\circ} \mathrm{C} \pm 5$ e umidade relativa de $65 \% \pm 10$. 


\subsubsection{Unidades experimentais}

As unidades experimentais, foram constituídas por 6 plantas de tiririca (Cyperus rotundus $\mathrm{L}$.), oriundas de 3 tubérculos pré-germinados, plantados em vasos com capacidade de 2,8 litros. Os vasos foram enchidos com uma mistura 3:1 de solo (Terra roxa estruturada) e esterco de vaca, curtido. As plantas foram irrigadas diariamente até a avaliação final.

\subsubsection{Delineamento experimental e tratamentos}

O delineamento experimental utilizado foi de blocos ao acaso com 4 repetições no esquema fatorial $5 \times 5$, num total de 25 tratamentos esquematizados na Tabela 1. Os tratamentos foram formados pela interação de cinco doses de glyphosate $(0,0 ; 0,18$; 0,$36 ; 0,72$ e 1,44 kg e.a./ha) com quatro adjuvantes além do glyphosate isolado.

Os adjuvantes testados foram, sulfato de amônio ( $2 \% \mathrm{p} / \mathrm{v})$; fosfato monoamônico $(2 \% \mathrm{p} / \mathrm{v})$; uréia $(2 \% \mathrm{p} / \mathrm{v})$ e surfactante $\mathrm{AF}(0,25 \% \mathrm{v} / \mathrm{v})$.

\subsubsection{Aplicação dos tratamentos}

Os tratamentos foram aplicados em 22/09/95, trinta dias após o plantio dos tubérculos, quando as plantas apresentavam $20 \mathrm{~cm}$ de altura e 8-10 folhas. 
As aplicações foram realizadas na câmara de aplicação com barra móvel, e pressão constante a $2,85 \mathrm{~kg} / \mathrm{cm}^{2}$ e com bicos Teejet 110.02 em leque. O volume de calda aplicado foi equivalente a $300 \mathrm{l} / \mathrm{ha}$.

Os herbicidas e adjuvantes, utilizados no experimento, com seus nomes químico e comercial, bem como as formulações e os fabricantes estão apresentados na Tabela 6.

Tabela 1. Esquema dos tratamentos componentes do experimento efeito de adjuvantes na eficácia do glyphosate. Volume de calda equivalente a $300 \mathrm{l} / \mathrm{ha}$.

\begin{tabular}{clc}
\hline Tratamento & Adjuvante (dose) & $\begin{array}{c}\text { Dose de glyphosate } \\
\text { (kg e.a./ha) }\end{array}$ \\
\hline 1 & Sem & 0,00 \\
2 & Sem & 0,18 \\
3 & Sem & 0,36 \\
4 & Sem & 0,72 \\
5 & Sem & 1,44 \\
6 & Sulfato de amônio $(2 \% \mathrm{p} / \mathrm{v})$ & 0,00 \\
7 & Sulfato de amônio $(2 \% \mathrm{p} / \mathrm{v})$ & 0,18 \\
8 & Sulfato de amônio $(2 \% \mathrm{p} / \mathrm{v})$ & 0,36 \\
9 & Sulfato de amônio $(2 \% \mathrm{p} / \mathrm{v})$ & 0,72 \\
10 & Sulfato de amônio $(2 \% \mathrm{p} / \mathrm{v})$ & 1,44 \\
11 & Fosfato monoamônico $(2 \% \mathrm{p} / \mathrm{v})$ & 0,00 \\
12 & Fosfato monomônico $(2 \% \mathrm{p} / \mathrm{v})$ & 0,18 \\
13 & Fosfato monoamônico $(2 \% \mathrm{p} / \mathrm{v})$ & 0,36 \\
14 & Fosfato monoamônico $(2 \% \mathrm{p} / \mathrm{v})$ & 0,72 \\
15 & Fosfato monoamônico $(2 \% \mathrm{p} / \mathrm{v})$ & 1,44 \\
16 & Uréia $(2 \% \mathrm{p} / \mathrm{v})$ & 0,00 \\
17 & Uréia $(2 \% \mathrm{p} / \mathrm{v})$ & 0,18 \\
18 & Uréia $(2 \% \mathrm{p} / \mathrm{v})$ & 0,36 \\
19 & Uréia $(2 \% \mathrm{p} / \mathrm{v})$ & 0,72 \\
20 & Uréia $(2 \% \mathrm{p} / \mathrm{v})$ & 1,44 \\
21 & Surfactante AF $(0,25 \% \mathrm{v} / \mathrm{v})$ & 0,00 \\
22 & Surfactante AF $(0,25 \% \mathrm{v} / \mathrm{v})$ & 0,18 \\
23 & Surfactante AF $(0,25 \% \mathrm{v} / \mathrm{v})$ & 0,36 \\
24 & Surfactante AF $(0,25 \% \mathrm{v} / \mathrm{v})$ & 0,72 \\
25 & Surfactante AF $(0,25 \% \mathrm{v} / \mathrm{v})$ & 1,44 \\
\hline
\end{tabular}




\subsubsection{Avaliação do experimento}

O efeito dos tratamentos foi determinado pela porcentagem de redução da rebrota das plantas tratadas em relação à testemunha (sem herbicidas). Para isto, 72 horas após a aplicação dos tratamentos, todas as plantas foram cortadas a $1 \mathrm{~cm}$ acima do nível do solo. Após a rebrota, 15 DAA (07/10/95) e 75 DAA (06/12/95) foram realizadas a primeira e segunda avaliação respectivamente; colhendo as manifestações epígeas com um corte raso e imediatamente pesadas para determinar a porcentagem da redução do peso da matéria fresca.

O efeito dos tratamentos na biomassa de subsuperficie (bulbos, rizomas, raízes e tubérculos) foi avaliado $75 \mathrm{DAA}$; para isso, logo após o corte das manifestações epígeas para sua avaliação, o solo contido em cada vaso foi lavado com água sob pressão, em uma peneira, retirando todas as manifestações de subsuperficie que logo após foram pesadas, determinando-se assim o peso da biomassa fresca.

\subsubsection{Análise estatística}

Os resultados obtidos foram submetidos a análise de variância, aplicando-se o teste $\mathrm{F}$ ao nível de $5 \%$ e $1 \%$ para testar as diferenças entre os efeitos das doses de glyphosate, dos adjuvantes e suas interações.

A comparação de médias foi realizada pelo teste de Tukey a $5 \%$. O efeito das doses de glyphosate isolado e dentro de cada adjuvante, foi expresso em equações de regressão. 
Os dados de porcentagem de redução do rebrote da primeira avaliação (15 DAA) foram transformados em arc sen $\sqrt{\mathrm{x} / 100}$ e os dados de peso da biomassa fresca subsuperficial transformados em $\sqrt{x^{+0,5}}$, conforme STEEL \& TORRIE (1981). A análise estatistica da segunda avaliação do rebrote a 75 DAA foi realizada com dados não transformados.

\subsection{Efeito do volume de calda, doses e adjuvantes na eficácia do glyphosate}

\subsubsection{Local}

$\mathrm{O}$ experimento foi conduzido em casa-de-vegetação. A temperatura média durante a condução do experimento foi mantida em $30^{\circ} \mathrm{C} \pm 5$ e umidade relativa de $65 \% \pm 10$.

\subsubsection{Unidades experimentais}

As unidades experimentais, foram constituídas por 6 plantas de tiririca (Cyperus rotundus L.), oriundas de 3 tubérculos pré-germinados, plantados em vasos com capacidade de 2,8 litros. Os vasos foram enchidos com uma mistura 3:1 de solo (Terra roxa estruturada) e esterco de vaca, curtido. As plantas foram irrigadas diariamente até a avaliação final. 


\subsubsection{Delineamento experimental e tratamentos}

O delineamento experimental utilizado foi de blocos ao acaso com 4 repetições, no esquema fatorial $3 \times 3 \times 3$, num total de 27 tratamentos, apresentados na Tabela 2.

Tabela 2. Esquema dos tratamentos correspondentes do experimento efeito de dose, volume de calda e adjuvantes na eficácia do glyphosate.

\begin{tabular}{cccl}
\hline Tratamento & $\begin{array}{c}\text { Dose de } \\
\text { glyphosate } \\
\text { kg e.a./ha }\end{array}$ & $\begin{array}{c}\text { Volume de calda } \\
\text { 1/ha }\end{array}$ & Adjuvante (dose) \\
\hline 1 & 0,36 & 150 & Sem \\
2 & 0,36 & 150 & Sulfato de amônio $(2 \% \mathrm{p} / \mathrm{v})$ \\
3 & 0,36 & 150 & Surfactante AF $(0,25 \% \mathrm{v} / \mathrm{v})$ \\
4 & 0,36 & 300 & Sem \\
5 & 0,36 & 300 & Sulfato de amônio $(2 \% \mathrm{p} / \mathrm{v})$ \\
6 & 0,36 & 300 & Surfactante AF $(0,25 \% \mathrm{v} / \mathrm{v})$ \\
7 & 0,36 & 450 & Sem \\
8 & 0,36 & 450 & Sulfato de amônio $(2 \% \mathrm{p} / \mathrm{v})$ \\
9 & 0,36 & 450 & Surfactante AF $(0,25 \% \mathrm{v} / \mathrm{v})$ \\
10 & 0,72 & 150 & Sem \\
11 & 0,72 & 150 & Sulfato de amônio $(2 \% \mathrm{p} / \mathrm{v})$ \\
12 & 0,72 & 150 & Surfactante AF $(0,25 \% \mathrm{v} / \mathrm{v})$ \\
13 & 0,72 & 300 & Sem \\
14 & 0,72 & 300 & Sulfato de amônio $(2 \% \mathrm{p} / \mathrm{v})$ \\
15 & 0,72 & 300 & Surfactante AF $(0,25 \% \mathrm{v} / \mathrm{v})$ \\
16 & 0,72 & 450 & Sem \\
17 & 0,72 & 450 & Sulfato de amônio $(2 \% \mathrm{p} / \mathrm{v})$ \\
18 & 0,72 & 450 & Surfactante AF $(0,25 \% \mathrm{v} / \mathrm{v})$ \\
19 & 1,44 & 150 & Sem \\
20 & 1,44 & 150 & Sulfato de amônio $(2 \% \mathrm{p} / \mathrm{v})$ \\
21 & 1,44 & 150 & Surfactante AF $(0,25 \% \mathrm{v} / \mathrm{v})$ \\
22 & 1,44 & 300 & Sem \\
23 & 1,44 & 300 & Sulfato de amônio $(2 \% \mathrm{p} / \mathrm{v})$ \\
24 & 1,44 & 300 & Surfactante AF $(0,25 \% \mathrm{v} / \mathrm{v})$ \\
25 & 1,44 & 450 & Sem \\
26 & 1,44 & 450 & Sulfato de amônio $(2 \% \mathrm{p} / \mathrm{v})$ \\
27 & 1,44 & 450 & Surfactante AF $(0,25 \% \mathrm{v} / \mathrm{v})$ \\
\hline
\end{tabular}


Os tratamentos foram formados pela combinação de três volumes de calda $(150 ; 300$ e $450 \mathrm{l} / \mathrm{ha})$, três doses de glyphosate $(0,36 ; 0,72$ e $1,44 \mathrm{~kg}$ e.a./ha), dois adjuvantes (sulfato de amônio $2 \% \mathrm{p} / \mathrm{v}$ e surfactante $\mathrm{AF} 0,25 \% \mathrm{v} / \mathrm{v}$ ) e glyphosate isolado.

\subsubsection{Aplicação dos tratamentos}

Os tratamentos foram aplicados em 23/09/95, trinta dias após o plantio (24/08/95), quando as plantas apresentaram $20 \mathrm{~cm}$ de altura e 8-10 folhas.

As aplicações foram realizadas na câmara de aplicação, barra móvel e pressão constante de $2,85 \mathrm{~kg} / \mathrm{cm}^{2}$ e com bicos Teejet 110.01 em leque para o volume de 150 1/ha; 110.02 para 300 l/ha e 110.03 para 450 l/ha.

As características dos produtos usados no experimento estão apresentados na Tabela 6.

\subsubsection{Avaliação do experimento}

$O$ efeito dos tratamentos foi determinado pela porcentagem de redução da rebrota das plantas tratadas em reląção à testemunha (sem herbicidas). Para isto, 72 horas após a aplicação dos tratamentos, todas as plantas foram cortadas a $1 \mathrm{~cm}$ acima do nivel do solo e após o rebrote, 15 DAA (08/10/95) foram colhidas as manifestações epígeas com um corte raso e imediatamente pesadas para determinar a porcentagem de redução do peso da matéria fresca. 


\subsubsection{Análise estatística}

Os resultados obtidos foram submetidos a análise de variância, aplicando o teste $\mathrm{F}$ aos níveis de $5 \%$ e $1 \%$ para testar as diferenças entre os efeitos principais de volume, dose, adjuvante e das interações de volume com dose, volume com adjuvante, dose com adjuvante e volume com dose e com adjuvante. A comparação das médias foi realizada pelo teste de Tukey a $5 \%$.

\subsection{Efeito dos sais e dos adjuvantes na eficácia do glyphosate}

\subsubsection{Local}

O experimento foi conduzido em vasos em ambiente não protegido.

\subsubsection{Unidades experimentais}

As unidades experimentais foram constituídas de 5 plantas de sorgo granífero (Sorghum bicolor), híbrido Pionner por vaso. Os vasos de $900 \mathrm{ml}$ de capacidade foram enchidos com mistura 3:1 de solo (Terra roxa estruturada) e esterco curtido de vaca. Foram semeadas 10 sementes por vaso e uma semana após a emergência foi realizado o desbaste. As plantas foram irrigadas diariamente até a avaliação final. 


\subsubsection{Delineamento experimental e tratamentos}

O delineamento experimental foi de blocos ao acaso com quatro repetições no esquema fatorial $6 \times 5$, num total de 30 tratamentos, esquematizados na Tabela 3.

Os tratamentos foram formados pela combinação dos cinco tipos de sais $\left(\mathrm{CaCl}_{2} 25 \mathrm{mM} ; \mathrm{MgCl}_{2} 25 \mathrm{mM}, \mathrm{NaHCO}_{3} 50 \mathrm{mM} ; \mathrm{FeSO}_{4} 10 \mathrm{mM}\right.$ e $\left.\mathrm{ZnSO}_{4} 10 \mathrm{mM}\right)$ e água desmineralizada e com uma dose de glyphosate $(0,18 \mathrm{~kg}$ e.a./ha) isolado e em mistura com quatro adjuvantes (surfactante AF $0,25 \% \mathrm{v} / \mathrm{v}$; sulfato de amônio $2 \% \mathrm{p} / \mathrm{v}$; Fosfato monoamônico $2 \% \mathrm{p} / \mathrm{v}$ e uréia $2 \% \mathrm{p} / \mathrm{v}$ ).

\subsubsection{Aplicạão dos tratamentos}

Os tratamentos foram aplicados quando as plantas de sorgo apresentaram 7-8 folhas ou $18 \mathrm{~cm}$ de altura $(11 / 10 / 95)$.

As aplicações foram realizadas na câmara de aplicação de barra móvel, a pressão constante de $2,85 \mathrm{~kg} / \mathrm{cm}^{2}$ com bicos Teejet $110.02 \mathrm{em}$ leque. $\mathrm{O}$ volume aplicado foi equivalente a $300 \mathrm{l} / \mathrm{ha}$.

As características dos produtos usados neste experimento estão apresentadas na Tabela 6 . 
Tabela 3. Esquema dos tratamentos componentes do experimento efeito dos sais na eficácia do glyphosate. Volume de calda equivalente a $300 \mathrm{l} / \mathrm{ha}$.

\begin{tabular}{|c|c|c|c|}
\hline Tratamento & $\begin{array}{l}\text { Glyphosate } \\
\mathrm{kg} \text { e.a./ha }\end{array}$ & Adjuvante (dose) & Sal - concentração \\
\hline 1 & 0,18 & Sem & Água desmineralizada \\
\hline 2 & 0,18 & Surfactante AF $(0,25 \% \mathrm{v} / \mathrm{v})$ & Água desmineralizada \\
\hline 3 & 0,18 & Sulfato de amônio $(2 \% \mathrm{p} / \mathrm{v})$ & Água desmineralizada \\
\hline 4 & 0,18 & Fosfato monoamônico $(2 \% \mathrm{p} / \mathrm{v})$ & Água desmineralizada \\
\hline 5 & 0,18 & Uréia $(2 \% \mathrm{p} / \mathrm{v})$ & Água desmineralizada \\
\hline 6 & 0,18 & Sem & $\mathrm{CaCl}_{2} 25 \mathrm{mM}$ \\
\hline 7 & 0,18 & Surfactante AF $(0,25 \% \mathrm{v} / \mathrm{v})$ & $\mathrm{CaCl}_{2} 25 \mathrm{mM}$ \\
\hline 8 & 0,18 & Sulfato de amônio $(2 \% \mathrm{p} / \mathrm{v})$ & $\mathrm{CaCl}_{2} 25 \mathrm{mM}$ \\
\hline 9 & 0,18 & Fosfato monoamônico $(2 \% \mathrm{p} / \mathrm{v})$ & $\mathrm{CaCl}_{2} 25 \mathrm{mM}$ \\
\hline 10 & 0,18 & Uréia $(2 \% \mathrm{p} / \mathrm{v})$ & $\mathrm{CaCl}_{2} 25 \mathrm{mM}$ \\
\hline 11 & 0,18 & Sem & $\mathrm{MgCl}_{2} 25 \mathrm{mM}$ \\
\hline 12 & 0,18 & Surfactante AF $(0,25 \% \mathrm{v} / \mathrm{v})$ & $\mathrm{MgCl}_{2} 25 \mathrm{mM}$ \\
\hline 13 & 0,18 & Sulfato de amônio $(2 \% \mathrm{p} / \mathrm{v})$ & $\mathrm{MgCl}_{2} 25 \mathrm{mM}$ \\
\hline 14 & 0,18 & Fosfato monoamônico $(2 \% \mathrm{p} / \mathrm{v})$ & $\mathrm{MgCl}_{2} 25 \mathrm{mM}$ \\
\hline 15 & 0,18 & Uréia $(2 \% \mathrm{p} / \mathrm{v})$ & $\mathrm{MgCl}_{2} 25 \mathrm{mM}$ \\
\hline 16 & 0,18 & Sem & $\mathrm{NaHCO}_{3} 50 \mathrm{mM}$ \\
\hline 17 & 0,18 & Surfactante AF $(0,25 \% \mathrm{v} / \mathrm{v})$ & $\mathrm{NaHCO}_{3} 50 \mathrm{mM}$ \\
\hline 18 & 0,18 & Sulfato de amônio $(2 \% \mathrm{p} / \mathrm{v})$ & $\mathrm{NaHCO}_{3} 50 \mathrm{mM}$ \\
\hline 19 & 0,18 & Fosfato monoamônico $(2 \% \mathrm{p} / \mathrm{v})$ & $\mathrm{NaHCO}_{3} 50 \mathrm{mM}$ \\
\hline 20 & 0,18 & Uréia $(2 \% \mathrm{p} / \mathrm{v})$ & $\mathrm{NaHCO}_{3} 50 \mathrm{mM}$ \\
\hline 21 & 0,18 & Sem & $\mathrm{FeSO}_{4} 10 \mathrm{mM}$ \\
\hline 22 & 0,18 & Surfactante AF $(0,25 \% \mathrm{v} / \mathrm{v})$ & $\mathrm{FeSO}_{4} 10 \mathrm{mM}$ \\
\hline 23 & 0,18 & Sulfato de amônio ( $2 \% \mathrm{p} / \mathrm{v})$ & $\mathrm{FeSO}_{4} 10 \mathrm{mM}$ \\
\hline 24 & 0,18 & Fosfato monoamônico $(2 \% \mathrm{p} / \mathrm{v})$ & $\mathrm{FeSO}_{4} 10 \mathrm{mM}$ \\
\hline 25 & 0,18 & Uréia $(2 \% \mathrm{p} / \mathrm{v})$ & $\mathrm{FeSO}_{4} 10 \mathrm{mM}$ \\
\hline 26 & 0,18 & Sem & $\mathrm{ZnSO}_{4} 10 \mathrm{mM}$ \\
\hline 27 & 0,18 & Surfactante $\mathrm{AF}(0,25 \% \mathrm{v} / \mathrm{v})$ & $\mathrm{ZnSO}_{4} 10 \mathrm{mM}$ \\
\hline 28 & 0,18 & Sulfato de amônio $(2 \% \mathrm{p} / \mathrm{v})$ & $\mathrm{ZnSO}_{4} 10 \mathrm{mM}$ \\
\hline 29 & 0,18 & Fosfato monoamônico $(2 \% \mathrm{p} / \mathrm{v})$ & $\mathrm{ZnSO}_{4} 10 \mathrm{mM}$ \\
\hline 30 & 0,18 & Uréia $(2 \% \mathrm{p} / \mathrm{v})$ & $\mathrm{ZnSO}_{4} 10 \mathrm{mM}$ \\
\hline
\end{tabular}




\subsubsection{Avaliação do experimento}

A fitotoxicidade dos tratamentos foi avaliada 10 DAA (21/10/95), cortando as plantas ao nível do solo e pesadas imediatamente para determinar a porcentagem de peso de matéria fresca em relação às plantas que não foram tratadas (testemunha geral).

\subsubsection{Análise estatística}

Os resultados obtidos foram submetidos a análise de variância, aplicando o teste $\mathrm{F}$ a $5 \%$ e $1 \%$ para testar as diferenças entre os efeitos dos sais, dos adjuvantes e suas interações. A comparação das médias foi realizada pelo teste de Tukey a $5 \%$.

Os dados de porcentagem de peso da matéria fresca, foram transformados em arc sen $\sqrt{\mathrm{x} / 100}$, conforme STEEL \& TORRIE (1981).

\subsection{Efeito da qualidade da água de diferentes fontes e dos adjuvantes na eficácia do glyphosate}

\subsubsection{Local}

O experimento foi conduzido em vasos em ambiente não protegido. 


\subsubsection{Unidades experimentais}

As unidades experimentais foram constituídas de 5 plantas de sorgo granífero (Sorghum bicolor), híbrido Pionner por vaso. Os vasos de $900 \mathrm{ml}$ de capacidade foram enchidos com mistura 3:1 de solo (Terra roxa estruturada) e esterco curtido de vaca. Foram semeadas 10 sementes por vaso e uma semana após a emergência foi realizado o desbaste. As plantas foram irrigadas diariamente até a avaliação final.

\subsubsection{Delineamento experimental e tratamentos}

O delineamento experimental foi em blocos ao acaso com 4 repetições no esquema fatorial $6 \times 5$, num total de 30 tratamentos, esquematizados na Tabela 4 .

Os tratamentos foram formados pela combinação de água provenientes de seis fontes (água desmineralizada, água da represa, água de manancial, água tratada, água de rio e água subterrânea) com uma dose de glyphosate $(0,36 \mathrm{~kg}$ e.a./ha) isolado e em mistura com cada um dos quatro adjuvantes (sulfato de amônio $2 \%$ p/v; fosfato monoamônico $2 \% \mathrm{p} / \mathrm{v}$; uréia $2 \% \mathrm{p} / \mathrm{v}$ e ácido cítrico $1 \% \mathrm{p} / \mathrm{v}$ ). 
Tabela 4. Esquema dos tratamentos componentes do experimento, efeito da qualidade da água de diferentes fontes e dos adjuvantes na eficácia do glyphosate. Volume de calda equivalente a $300 \mathrm{l} / \mathrm{ha}$.

\begin{tabular}{|c|c|c|c|}
\hline Tratamento & Fonte de água & $\begin{array}{l}\text { Glyphosate } \\
\text { kg e.a./ha }\end{array}$ & Adjuvante (dose) \\
\hline 1 & Água desmineralizada & 0,36 & Sem \\
\hline 2 & Água desmineralizada & 0,36 & Sulfato de amônio $(2 \% \mathrm{p} / \mathrm{v})$ \\
\hline 3 & Água desmineralizada & 0,36 & Fosfato monoamônico $(2 \% \mathrm{p} / \mathrm{v})$ \\
\hline 4 & Água desmineralizada & 0,36 & Uréia $(2 \% \mathrm{p} / \mathrm{v})$ \\
\hline 5 & Água desmineralizada & 0,36 & Ácido cítrico $(1 \% \mathrm{p} / \mathrm{v})$ \\
\hline 6 & Água de represa & 0,36 & Sem \\
\hline 7 & Água de represa & 0,36 & Sulfato de amônio $(2 \% \mathrm{p} / \mathrm{v})$ \\
\hline 8 & Água de represa & 0,36 & Fosfato monoamônico $(2 \% \mathrm{p} / \mathrm{v})$ \\
\hline 9 & Água de represa & 0,36 & Uréia (2\% p/v) \\
\hline 10 & Água de represa & 0,36 & Ácido cítrico $(1 \% \mathrm{p} / \mathrm{v})$ \\
\hline 11 & Água de manancial & 0,36 & Sem \\
\hline 12 & Água de manancial & 0,36 & Sulfato de amônio $(2 \% \mathrm{p} / \mathrm{v})$ \\
\hline 13 & Água de manancial & 0,36 & Fosfato monoamônico $(2 \% \mathrm{p} / \mathrm{v})$ \\
\hline 14 & Agua de manancial & 0,36 & Uréia $(2 \% \mathrm{p} / \mathrm{v})$ \\
\hline 15 & Agua de manancial & 0,36 & Acido cítrico $(1 \% \mathrm{p} / \mathrm{v})$ \\
\hline 16 & $\begin{array}{l}\text { Agua tratada } \\
\text { (torneira) }\end{array}$ & 0,36 & Sem \\
\hline 17 & $\begin{array}{l}\text { Agua tratada } \\
\text { (torneira) }\end{array}$ & 0,36 & Sulfato de amônio $(2 \% \mathrm{p} / \mathrm{v})$ \\
\hline 18 & $\begin{array}{l}\text { Água tratada } \\
\text { (torneira) }\end{array}$ & 0,36 & Fosfato monoamônico $(2 \% \mathrm{p} / \mathrm{v})$ \\
\hline 19 & $\begin{array}{l}\text { Agua tratada } \\
\text { (torneira) }\end{array}$ & 0,36 & Uréia $(2 \% \mathrm{p} / \mathrm{v})$ \\
\hline 20 & $\begin{array}{l}\text { Agua tratada } \\
\text { (torneira) }\end{array}$ & 0,36 & Acido cítrico $(1 \% \mathrm{p} / \mathrm{v})$ \\
\hline 21 & $\begin{array}{l}\text { Agua do Rio } \\
\text { Piracicaba }\end{array}$ & 0,36 & Sem \\
\hline 22 & $\begin{array}{l}\text { Água do Rio } \\
\text { Piracicaba }\end{array}$ & 0,36 & Sulfato de amônio $(2 \% \mathrm{p} / \mathrm{v})$ \\
\hline 23 & $\begin{array}{l}\text { Água do Rio } \\
\text { Piracicaba }\end{array}$ & 0,36 & Fosfato monoamônico $(2 \% \mathrm{p} / \mathrm{v})$ \\
\hline 24 & $\begin{array}{l}\text { Água do Rio } \\
\text { Piracicaba }\end{array}$ & 0,36 & Uréia $(2 \% \mathrm{p} / \mathrm{v})$ \\
\hline 25 & $\begin{array}{l}\text { Agua do Rio } \\
\text { Piracicaba }\end{array}$ & 0,36 & Acido cítrico $(1 \% \mathrm{p} / \mathrm{v})$ \\
\hline 26 & Agua subterrânea & 0,36 & Sem \\
\hline 27 & Agua subterrânea & 0,36 & Sulfato de amônio $(2 \% \mathrm{p} / \mathrm{v})$ \\
\hline 28 & Agua subterrânea & 0,36 & Fosfato monoamônico $(2 \% \mathrm{p} / \mathrm{v})$ \\
\hline 29 & Agua subterrânea & 0,36 & Uréia $(2 \% \mathrm{p} / \mathrm{v})$ \\
\hline 30 & Agua subterrânea & 0,36 & Acido cítrico $(1 \% \mathrm{p} / \mathrm{v})$ \\
\hline
\end{tabular}




\subsubsection{Aplicação dos tratamentos}

Os tratamentos foram aplicados quando as plantas de sorgo apresentaram 7-8 folhas ou $18 \mathrm{~cm}$ de altura (11/11/95).

As aplicações foram realizadas na câmara de aplicação de barra móvel, a pressão constante de $2,85 \mathrm{~kg} / \mathrm{cm}^{2}$ com bicos Teejet 110.02 em leque. O volume aplicado foi equivalente a $300 \mathrm{l} / \mathrm{ha}$.

As características dos produtos usados neste experimento estão apresentadas na Tabela 6

As amostras de água das diferentes fontes foram tiradas num balde de 10 litros de capacidade; dois litros da amostra foram para a análise no Laboratório de Hidrologia, do Setor de Hidrologia Florestal da ESALQ/USP; o resto foi engarrafado e mantido em geladeira até o dia da aplicação (11/11/95). Os dados sobre a análise de água das diferentes fontes apresentam-se na Tabela 5 .

\subsubsection{Avaliação do experimento}

A fitotoxicidade dos tratamentos foi avaliada 10 DAA (21/11/95), cortando as plantas ao nível do solo e pesando-se imediatamente para determinar a porcentagem de peso de matéria fresca em relação às plantas que não foram tratadas (testemunha geral). 


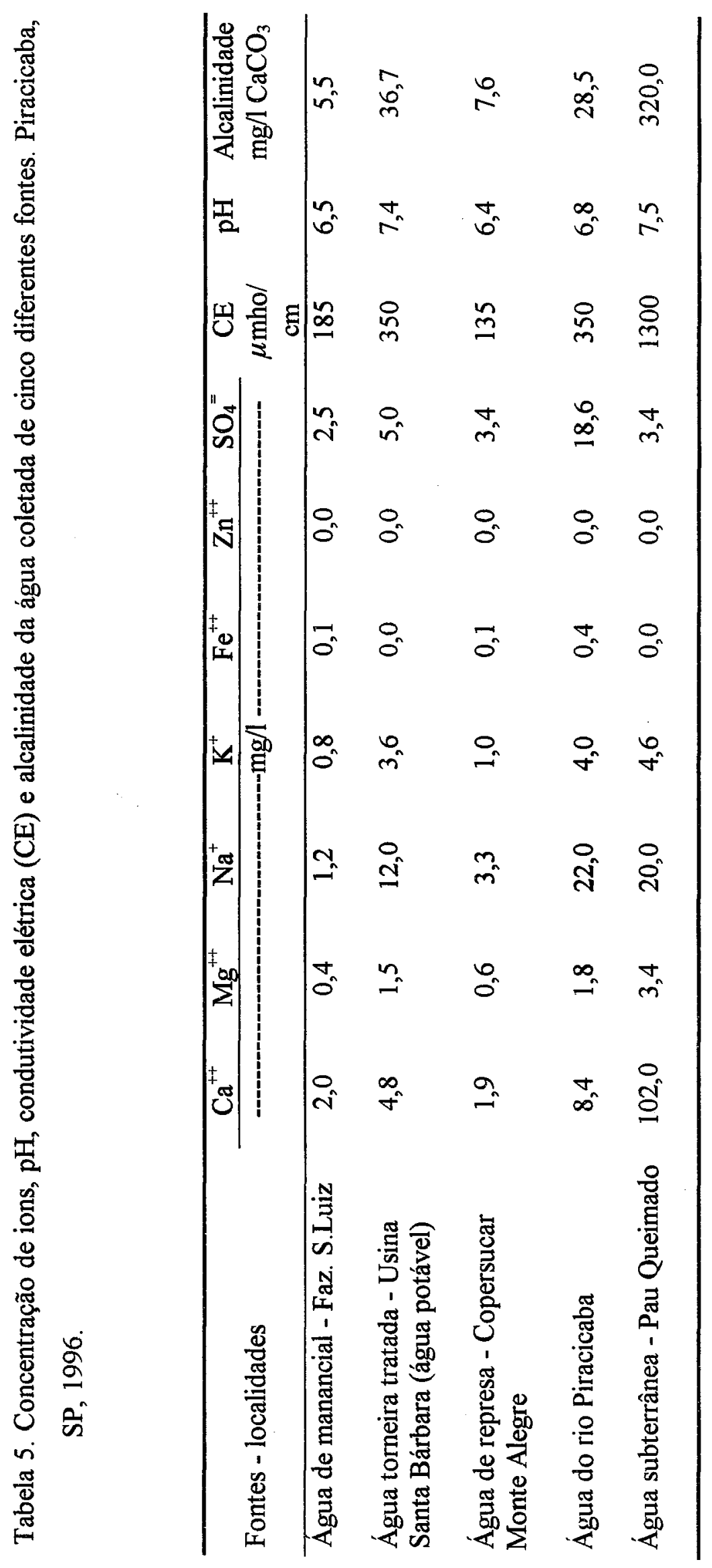




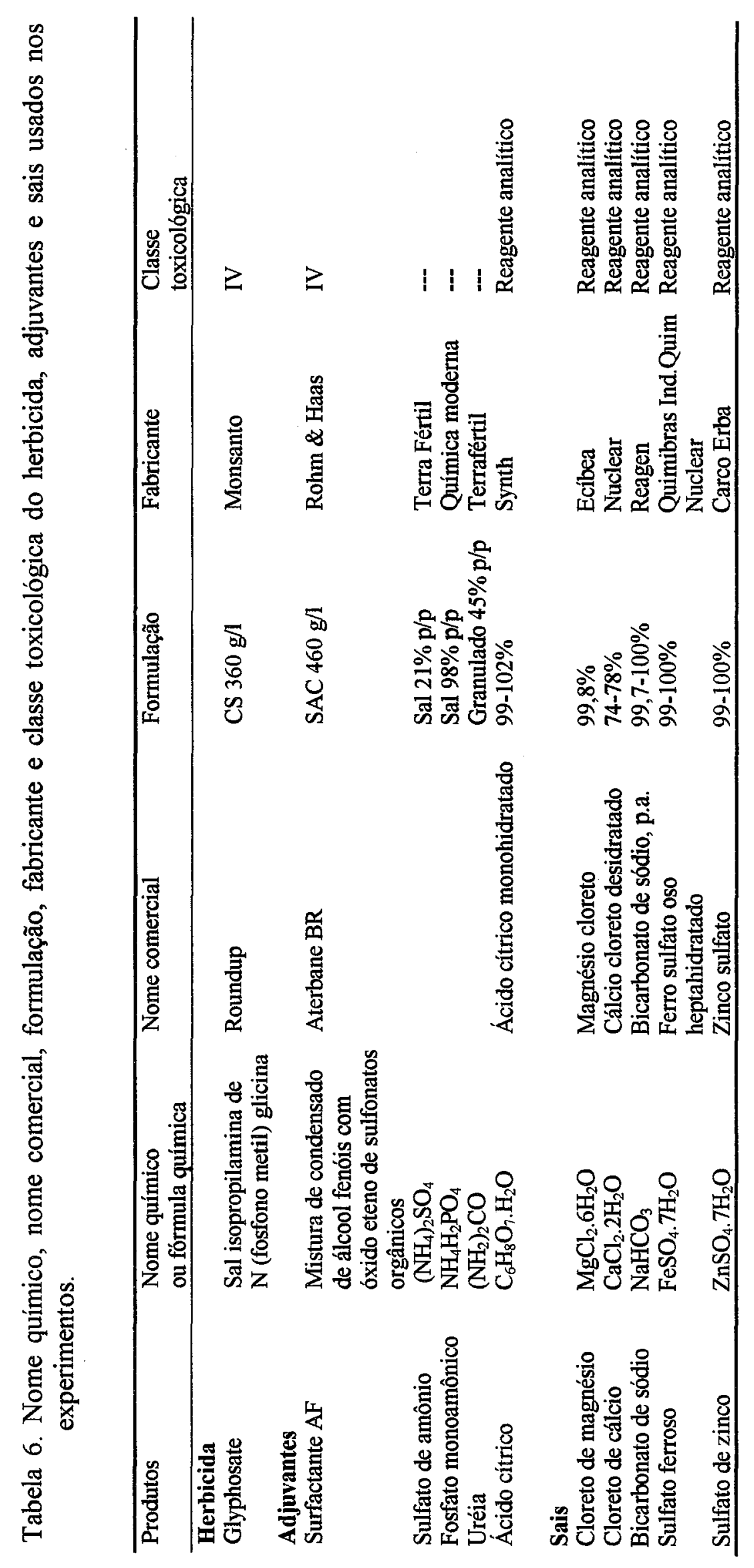




\subsubsection{Análise estatística}

Os resultados obtidos foram submetidos a análise de variância, aplicando o teste $\mathrm{F}$ a $5 \%$ e $1 \%$ para determinar as diferenças entre os efeitos das fontes, adjuvantes e suas interações. A comparação das médias foi realizada pelo teste de Tukey a $5 \%$. 


\section{RESULTADOS E DISCUSSÃO}

\subsection{Efeito dos adjuvantes na eficácia do glyphosate}

Os resultados da primeira avaliação, 15 diảs após a aplicação (15 DAA) apresentados na Tabela 7 e Figura 1, mostram que os adjuvantes afetaram a eficácia do glyphosate no controle de $C$. rotundus.

As maiores porcentagens de controle foram obtidas com os adjuvantes sulfato de amônio, uréia e fosfato monoamônico. Os aumentos com relação ao glyphosate isolado foram significativos na dose mais baixa $(0,18 \mathrm{~kg}$ e.a./ha). $O$ sulfato de amônio aumentou $23,6 \%$, a uréia $15,3 \%$ e o fosfato monoamônico $14,7 \%$ e não houve diferença entre eles. Os aumentos observados nas doses maiores $(0,36 ; 0,72$ e $1,44 \mathrm{~kg}$ e.a./ha), devido à ação dos adjuvantes, não foram significativos.

O surfactante AF testado neste experimento, causou um efeito negativo, diminuindo significativamente o controle em $34,5 \%$ com relação a glyphosate isolado, na dose mais baixa $(0,18 \mathrm{~kg}$ e.a. $/ \mathrm{ha})$; nas outras doses, não apresentou efeito significativo. 
Com relação ao efeito das doses de glyphosate, pode-se notar na Tabela 7, que o nível de controle foi elevado a partir da dose $0,36 \mathrm{~kg}$ e.a./ha. O controle com as duas maiores doses 0,72 e $1,44 \mathrm{~kg}$ e.a./ha foi o mesmo, já que as diferenças não foram significativas. No entanto, a dose mais alta superou as mais baixas; e $0,72 \mathrm{~kg}$ e.a./ha foi superior a 0,18 e igual a $0,36 \mathrm{~kg}$ e.a. $/ \mathrm{ha}$; tudo isto é válido para glyphosate sem e com adjuvantes, com exceção do sulfato de amônio, que aumentou o controle da dose $0,36 \mathrm{~kg}$ e.a./ha ao mesmo nivel de 0,72 e $1,44 \mathrm{~kg}$ e.a. $/ \mathrm{ha}$.

Tabela 7. Efeito da interação de adjuvantes com doses de glyphosate, no controle de $C$. rotundus L., expresso em porcentagem de redução do rebrote. 15 DAA. Piracicaba, SP, 1996.

\begin{tabular}{|c|c|c|c|c|c|}
\hline \multirow[b]{2}{*}{ Adjuvantes (A) } & \multicolumn{5}{|c|}{ Doses de glyphosate (D) (kg e.a./ha) } \\
\hline & 0,0 & 0,18 & 0,36 & 0,72 & 1,44 \\
\hline Sem & $0,0 \mathrm{a} \mathrm{D}^{(1)}$ & 69,2 b C & $92,7 \mathrm{ab} \mathrm{B}$ & 98,3 a $\mathrm{AB}$ & 99,9 a A \\
\hline Sulfato de amônio & $0,0 \mathrm{a} \mathrm{C}$ & 92,8 a B & 97,9 a $\mathrm{AB}$ & 99,8 a A & 100,0 a A \\
\hline Fosfato monoamônico & 0,0 a D & 83,9 a C & 96,7 a $B$ & 98,9 a $\mathrm{AB}$ & 100,0 a $\mathrm{A}$ \\
\hline Uréia & 0,0 a D & 84,5 a $C$ & 95,8 a $\mathrm{B}$ & 99,8 a $A B$ & 100,0 a $\mathrm{A}$ \\
\hline Surfactante AF & 0,0 a D & $34,9 \mathrm{c} \mathrm{C}$ & 83,9 b $\quad$ B & 99,8 a $\mathrm{A}$ & 99,9 a A \\
\hline $\mathrm{F}(\mathrm{AxD})^{(2)}$ & & - & $6,88 * *$ & & \\
\hline C.V. (\%) & 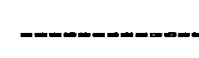 & 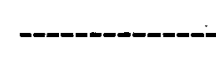 & 7,93 & $\ldots$ & .-- \\
\hline
\end{tabular}




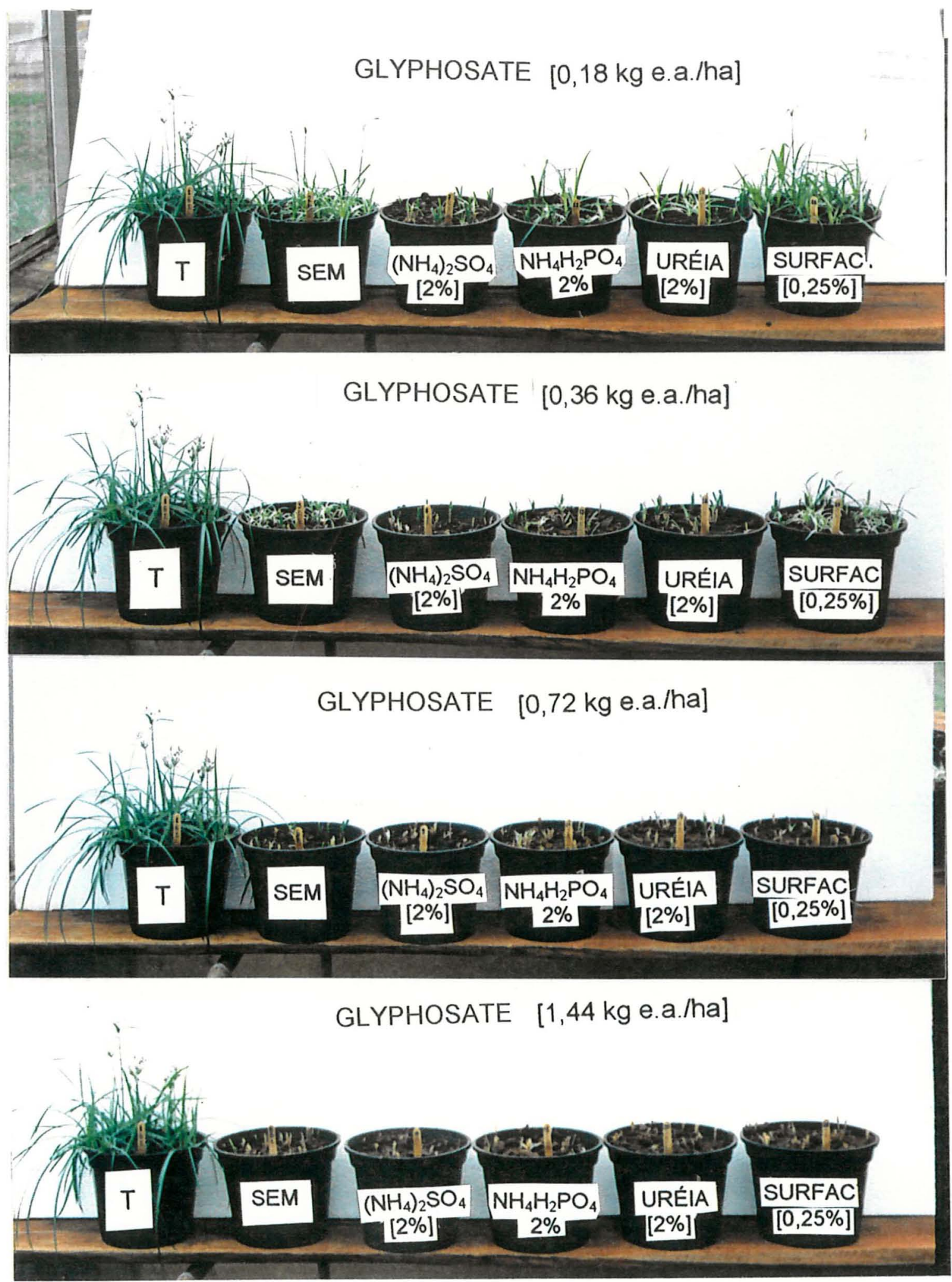

Figura 1. Efeito das doses de glyphosate isolado e com adjuvantes na redução do rebrote de Cyperus rotundus L. 15 DAA. Piracicaba, SP, 1996. 
Na segunda avaliação 75 DAA, como pode-se observar na Tabela 8 e Figura 2, as doses baixas de glyphosate $(0,18$ e $0,36 \mathrm{~kg}$ e.a./ha) não mantiveram o controle de C. rotundus, apresentado aos $15 \mathrm{DAA}$; as plantas rebrotaram e não houve efeito do herbicida à exceção dos tratamentos com adição de sulfato de amônio e uréia, os quais mantiveram controle significativo na dose $0,36 \mathrm{~kg}$ e.a. $/ \mathrm{ha}$, com 82,3 e $28,0 \%$ respectivamente.

O sulfato de amônio e a uréia, elevaram também significativamente o nível de controle da dose $0,72 \mathrm{~kg}$ e.a./ha de glyphosate, em 15 e $14 \%$ respectivamente. $\mathrm{O}$ fosfato monoamônico não aumentou a eficácia do glyphosate em nenhuma das doses. Entretanto, o surfactante AF diminuiu o controle da dose $0,72 \mathrm{~kg}$ e.a./ha de glyphosate mas a diferença não foi significativa a $5 \%$. Nas outras doses, não modificou o efeito do glyphosate.

Com relação ao efeito das doses, como pode-se observar na Tabela 8 , para glyphosate com sulfato de amônio e glyphosate com uréia, a redução da rebrota de $C$. rotundus foi igual para as doses 1,44 e $0,72 \mathrm{~kg}$ e.a./ha, pois as diferenças não foram significativas. Por sua vez, estas duas doses superaram significativamente as menores. Segundo a análise de regressão polinomial, no intervalo de doses testadas, estes tratamentos apresentaram um efeito quadrático no controle da rebrota de $C$. rotundus, evidenciando assim, o efeito destes adjuvantes na eficácia do glyphosate (Figuras 4 e 6).

No entanto, para glyphosate isolado, glyphosate com fosfato monoamônico e glyphosate com surfactante $\mathrm{AF}$, o controle com a maior dose $(1,44 \mathrm{~kg}$ e.a./ha) foi significativamente superior às doses menores (Tabela 8); e segundo a análise de regressão polinomial (Figuras 3, 5 e 7), os efeitos do controle de $C$. rotundus foram lineares, ou seja, a maior dose de glyphosate obteve o maior controle, o que demonstra que não houve efeito destes adjuvantes no intervalo das doses testadas. 
Tabela 8. Efeito da interação de adjuvantes com doses de glyphosate, no controle de $C$. rotundus L., expresso em porcentagem de redução do rebrote. 75 DAA. Piracicaba, SP, 1996.

\begin{tabular}{|c|c|c|c|c|c|}
\hline \multirow[b]{2}{*}{ Adjuvantes (A) } & \multicolumn{5}{|c|}{ Doses de glyphosate (D) (kg e.a./ha) } \\
\hline & 0,0 & 0,18 & 0,36 & 0,72 & 1,44 \\
\hline Sem & 0,0 a $\mathrm{C}^{(1)}$ & $0,0 \mathrm{a} \mathrm{C}$ & $0,0 \mathrm{c} \mathrm{C}$ & $82,5 \mathrm{bB}$ & 100,0 a $\mathrm{A}$ \\
\hline Sulfato de amônio & 0,0 a C & $0,0 \mathrm{a} \mathrm{C}$ & 82,3 a B & 97,5 a $\mathrm{A}$ & $100,0 \mathrm{a} \mathrm{A}$ \\
\hline Fosfato monoamônico & 0,0 a C & 0,0 a C & $0,0 \mathrm{c} \mathrm{C}$ & 82,5 b B & 100,0 a A \\
\hline Uréia & 0,0 a C & 0,0 a C & 28,0 b B & 96,5 a $\mathrm{A}$ & $100,0 \mathrm{a} \mathrm{A}$ \\
\hline Surfactante AF & 0,0 a C & 0,0 a C & $0,0 \mathrm{c} \mathrm{C}$ & 77,5 b B & 100,0 a A \\
\hline$F(A \times B)$ & --------.--- & $\ldots$ & $43,9 * *$ & -------.-- & 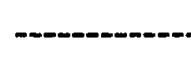 \\
\hline C.V. $(\%)$ & ----------- & ------ & 11,3 & ---- & $\ldots$ \\
\hline
\end{tabular}

Os resultados da interação dos adjuvantes com as doses de glyphosate na redução da biomassa de subsuperficie de $C$. rotundus constantes na Tabela 9 , mostram que só sulfato de amônio e uréia aumentaram significativamente a redução da biomassa de subsuperficie nas doses de glyphosate 0,36 e $0,72 \mathrm{~kg}$ e.a. $/ \mathrm{ha}$. Na dose de $0,36 \mathrm{~kg}$ e.a. $/ \mathrm{ha}$ a redução foi $39,8 \%$ maior pelo sulfato de amònio e $34,0 \%$ pela uréia. $\mathrm{Na}$ dose de $0,72 \mathrm{~kg}$ e.a./ha, em 51,8 e $51,3 \%$ respectivamente. Nas doses menores, não houve redução mesmo com adjuvantes; no entanto, na dose maior houve $100 \%$ de redução para todas as combinações. 

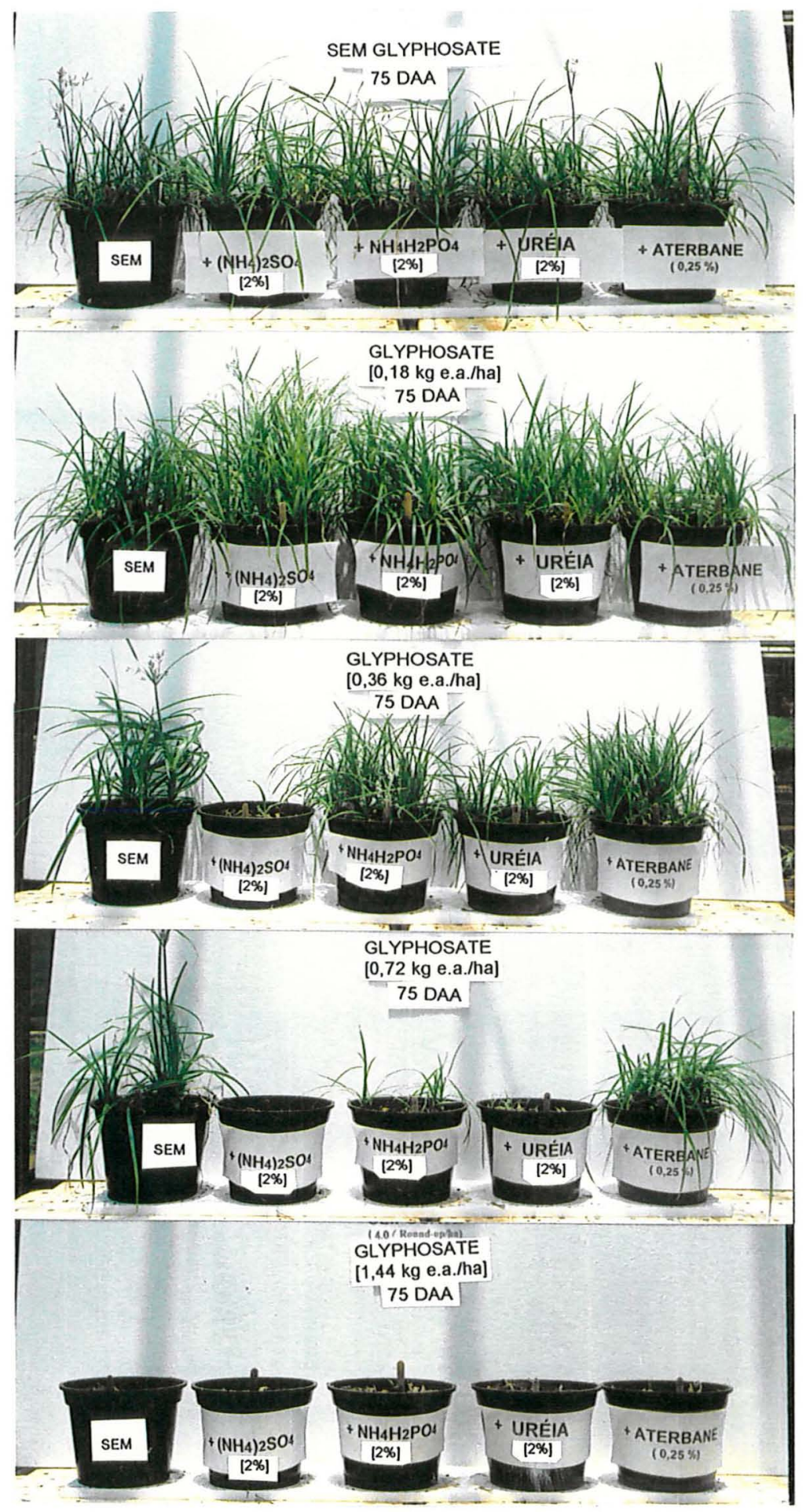

Figura 2. Efeito das doses de glyphosate isolado e com adjuvantes na redução do rebrote de Cyperus rotundus L. 75 DAA. Piracicaba, SP, 1996. 


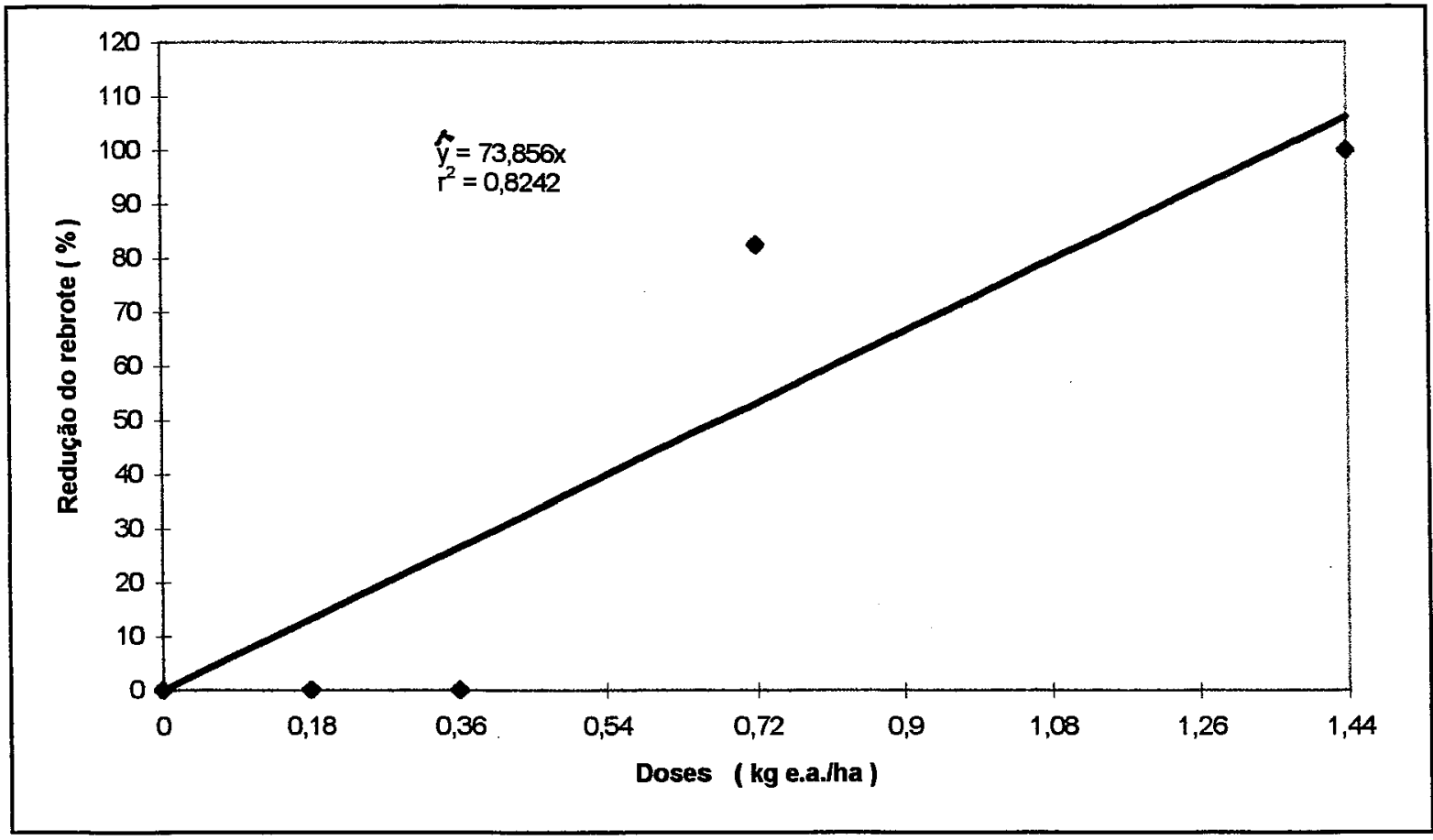

Figura 3. Efeito das doses de glyphosate sem adjuvantes na redução do rebrote de $C$. rotundus $\mathrm{L}$. 75 DAA.

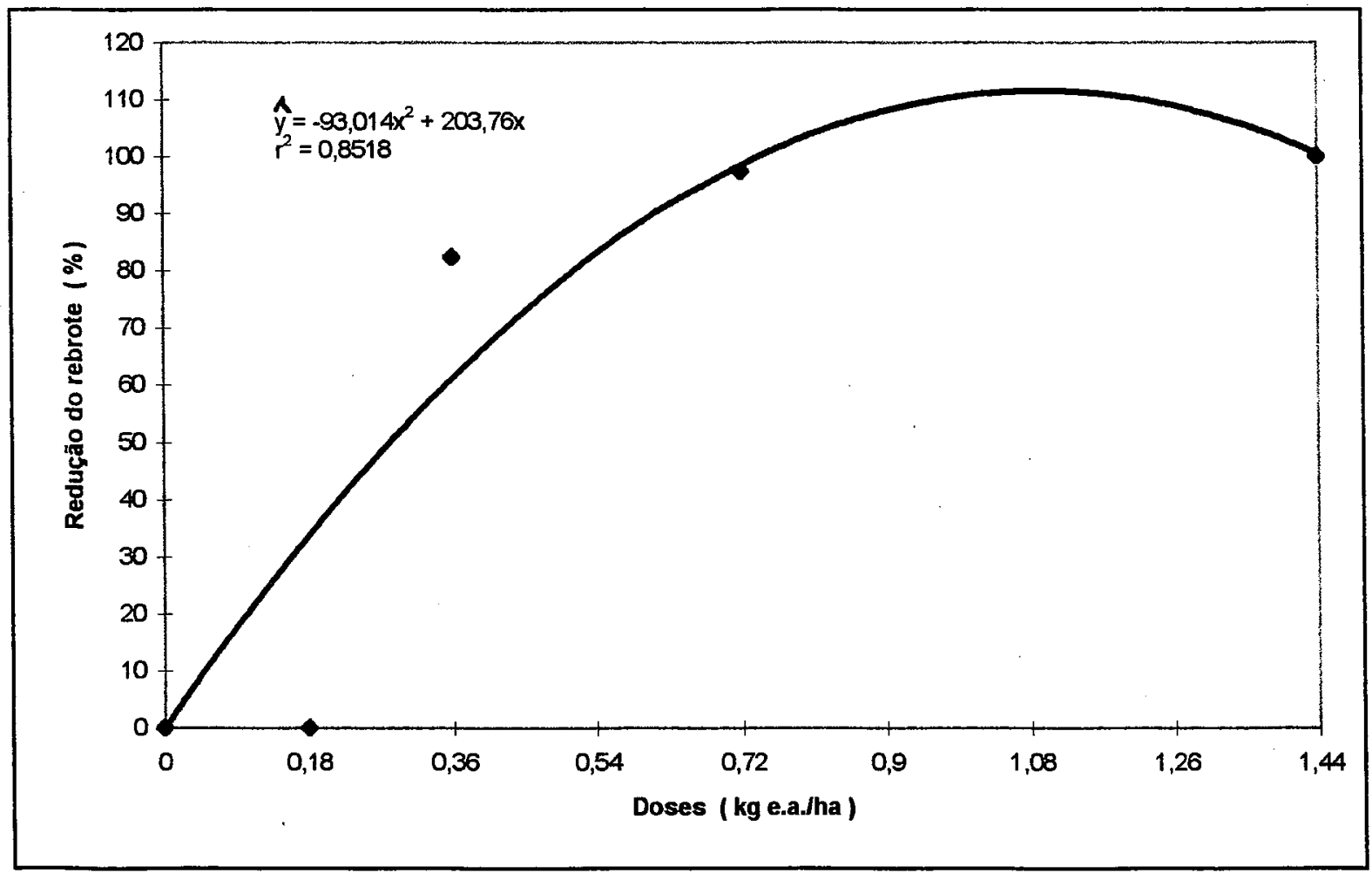

Figura 4. Efeito das doses de glyphosate com sulfato de amônio na redução do rebrote de $C$. rotundus L. 75 DAA. 


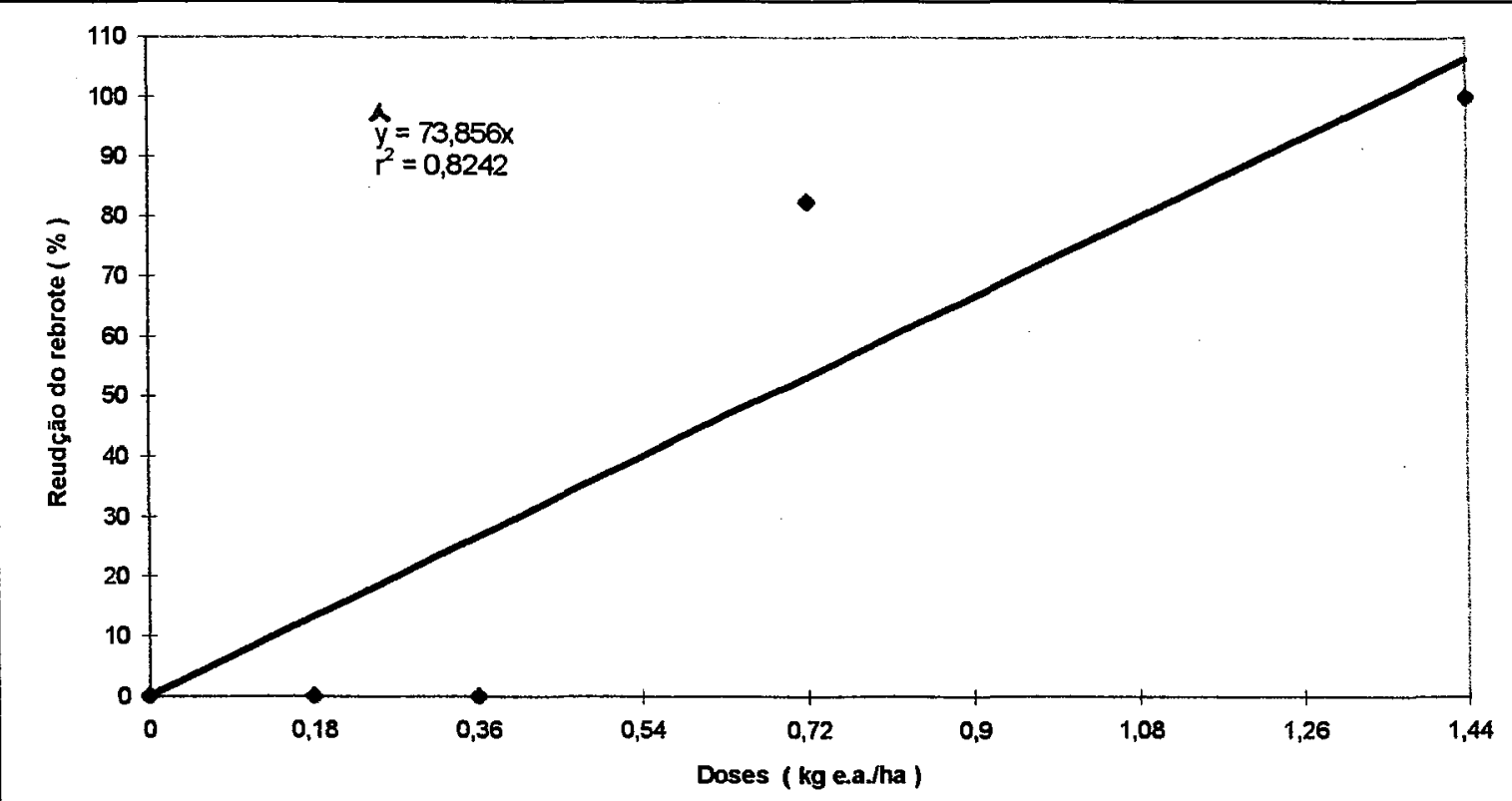

Figura 5. Efeito das doses de glyphosate com fosfato monoamônico na redução do rebrote de $C$. rotundus $\mathrm{L}$. 75 DAA.

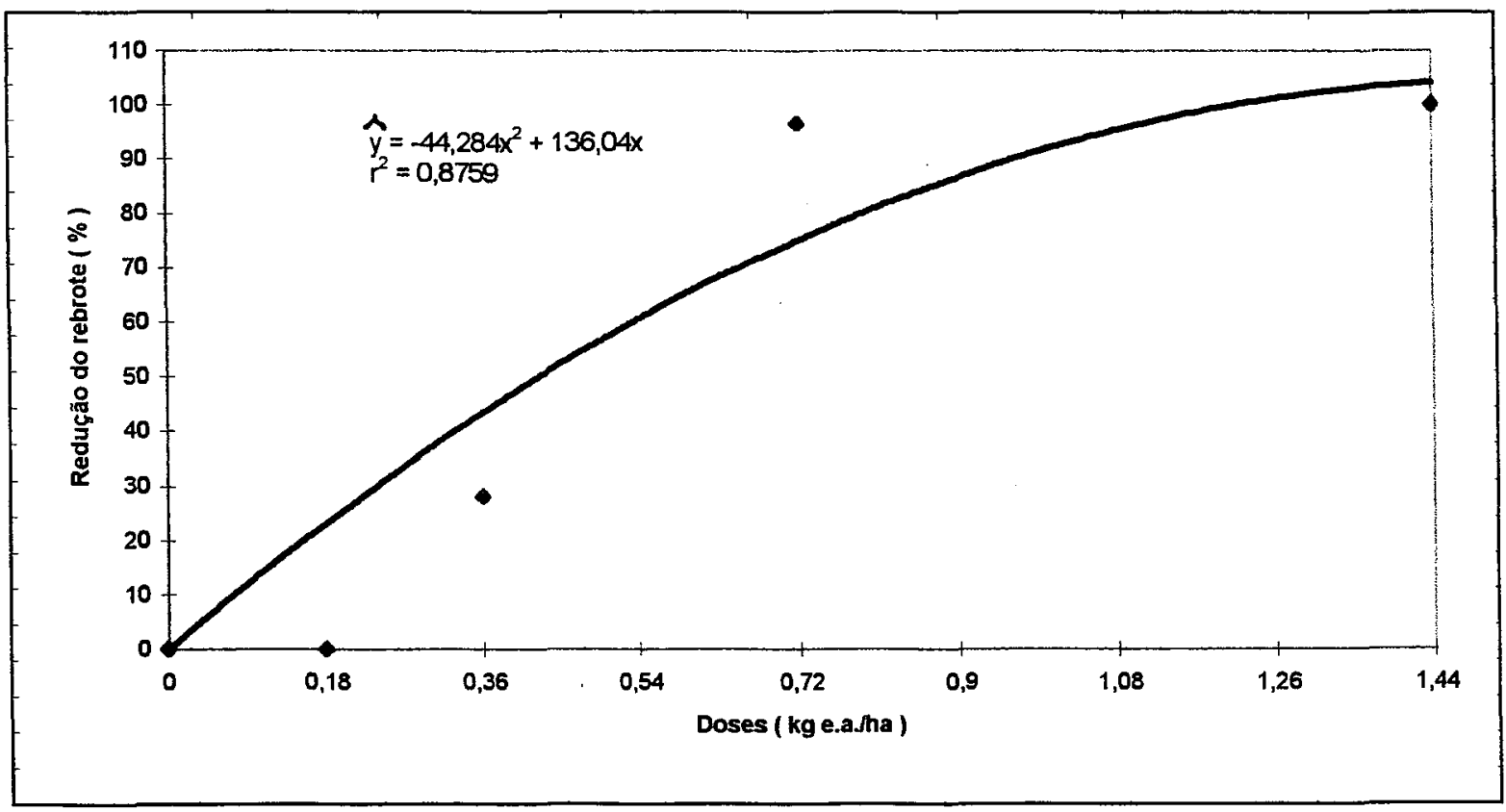

Figura 6. Efeito das doses de glyphosate com uréia na redução do rebrote de C. rotundus $\mathrm{L}$. 75 DAA. 


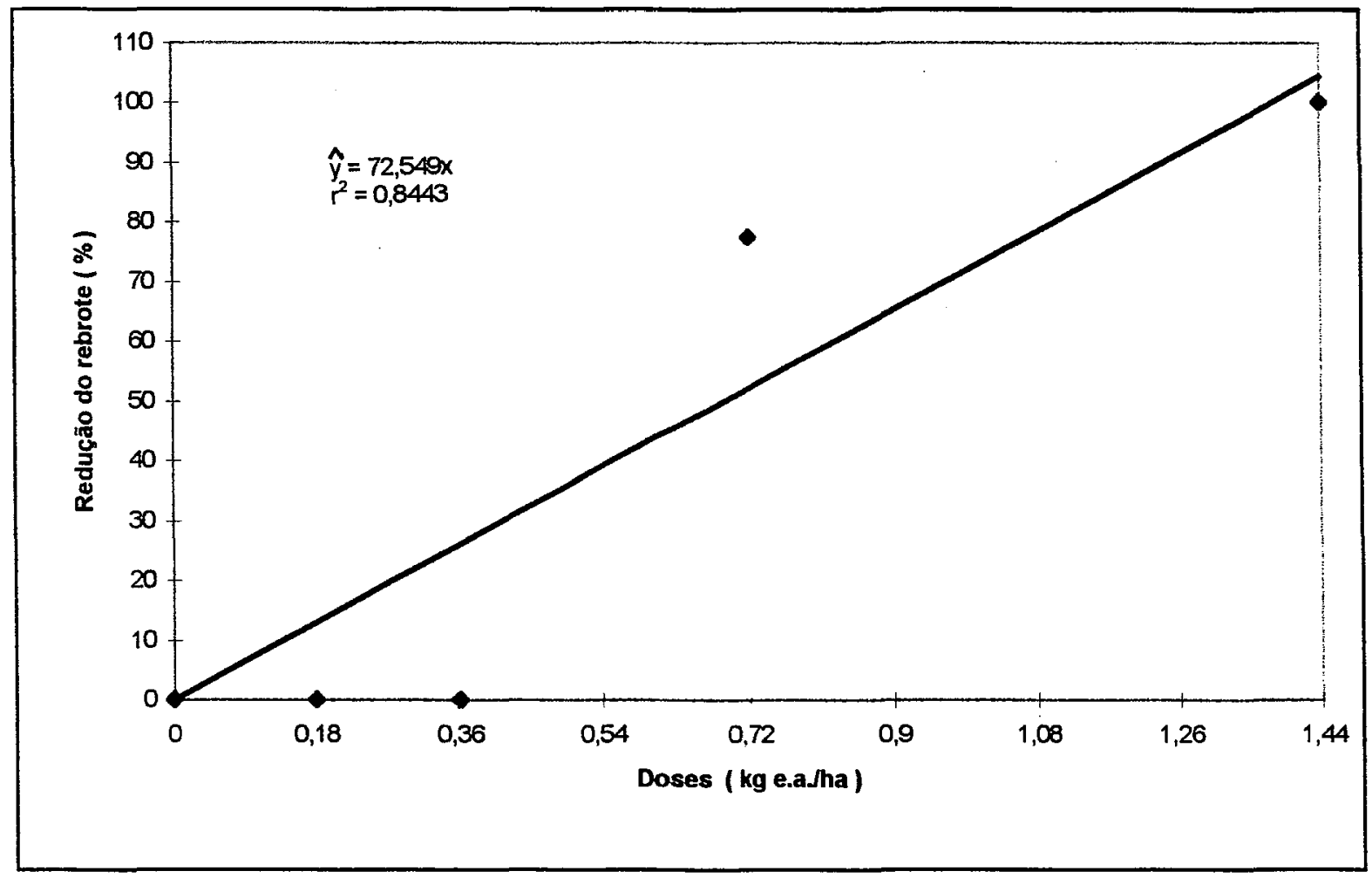

Figura 7. Efeito das doses de glyphosate com surfactante $\mathrm{AF}$ na redução do rebrote de $C$. rotundus L. 75 DAA.

$\mathrm{O}$ fosfato monoamônico e o surfactante $\mathrm{AF}$ não aumentaram significativamente a eficácia do glyphosate em nenhuma das doses

Verificou-se que quando foi usado glyphosate com sulfato de amônio ou com uréia, o nível da redução da biomassa de sub-superficie com $0,72 \mathrm{~kg}$ e.a./ha foi igual a $1,44 \mathrm{~kg}$ e.a./ha (o dobro da anterior), pois as diferenças não foram significativas (Tabela 9). Segundo as análises de regressão polinomial, para as doses de glyphosate com sulfato de amônio e glyphosate com uréia, os efeitos da redução da biomassa de subsuperficie foram quadráticos, como pode observar-se nas Figuras 7 e 9, respectivamente; ou seja, houve efeito desses adjuvantes na eficácia do glyphosate. 
Tabela 9. Efeito da interação de adjuvantes com doses de glyphosate, na redução da biomassa de subsuperficie de $C$. rotundus $\mathrm{L}$., expresso em porcentagem aos 75 DAA. Piracicaba, SP, 1996.

\begin{tabular}{|c|c|c|c|c|c|}
\hline \multirow[b]{2}{*}{ Adjuvantes (A) } & \multicolumn{5}{|c|}{ Doses de glyphosate (D) (kg e.a./ha) } \\
\hline & 0,0 & 0,18 & 0,36 & 0,72 & 1,44 \\
\hline Sem & $0,0 \mathrm{a} \mathrm{C}^{(1)}$ & $0,0 \mathrm{a} \mathrm{C}$ & 25,0 b B & 43,5 c B & 96,0 a $\mathrm{A}$ \\
\hline Sulfato de amônio & 0,0 a C & 0,0 a C & 64,8 a B & 95,3 a $\mathrm{A}$ & 97,3 a A \\
\hline Fosfato monoamônico & 0,0 a D & 0,0 a D & $28,5 \mathrm{~b} \mathrm{C}$ & $67,0 \mathrm{~b} \mathrm{~B}$ & 96,0 a A \\
\hline Uréia & 0,0 a C & 0,0 a C & 59,0 a B & 94,8 a A & 94,0 a A \\
\hline Surfactante AF & 0,0 a C & 0,0 a C & $0,0 \mathrm{c} \mathrm{C}$ & $65,0 \mathrm{~b} \mathrm{~B}$ & 92,0 a A \\
\hline $\mathrm{F}(\mathrm{AxD})$ & ---------. & --.---. & $7,4 * *$ & ------- & $\ldots$ \\
\hline C.V. (\%) & -.--_-_-_.-. & .---- & 24,9 & --.-- & $\ldots$ \\
\hline
\end{tabular}

(1) Médias com a mesma letra, minúsculas nas colunas e maiúsculas nas linhas, não apresentam diferença significativa segundo o teste de Tukey a 5\% de probabilidade.

** Significativos ao nível de $1 \%$ de probabilidade.

No entanto, para glyphosate isolado, glyphosate com fosfato monoamônico e glyphosate com surfactante $\mathrm{AF}$, a dose mais alta $1,44 \mathrm{~kg}$ e.a./ha teve uma redução significativamente maior que as doses menores (Tabela 9) e segundo a análise de regressão, as doses de glyphosate isolado e com esses adjuvantes tiveram um efeito linear na redução da biomassa de subsuperficie de $C$. rotundus (Figuras 6, 8 e 10), ou seja, não houve efeito desses adjuvantes na eficácia do glyphosate e, portanto, quanto maior a dose de glyphosate maior redução, nas condições deste experimento e nessa faixa de doses. 


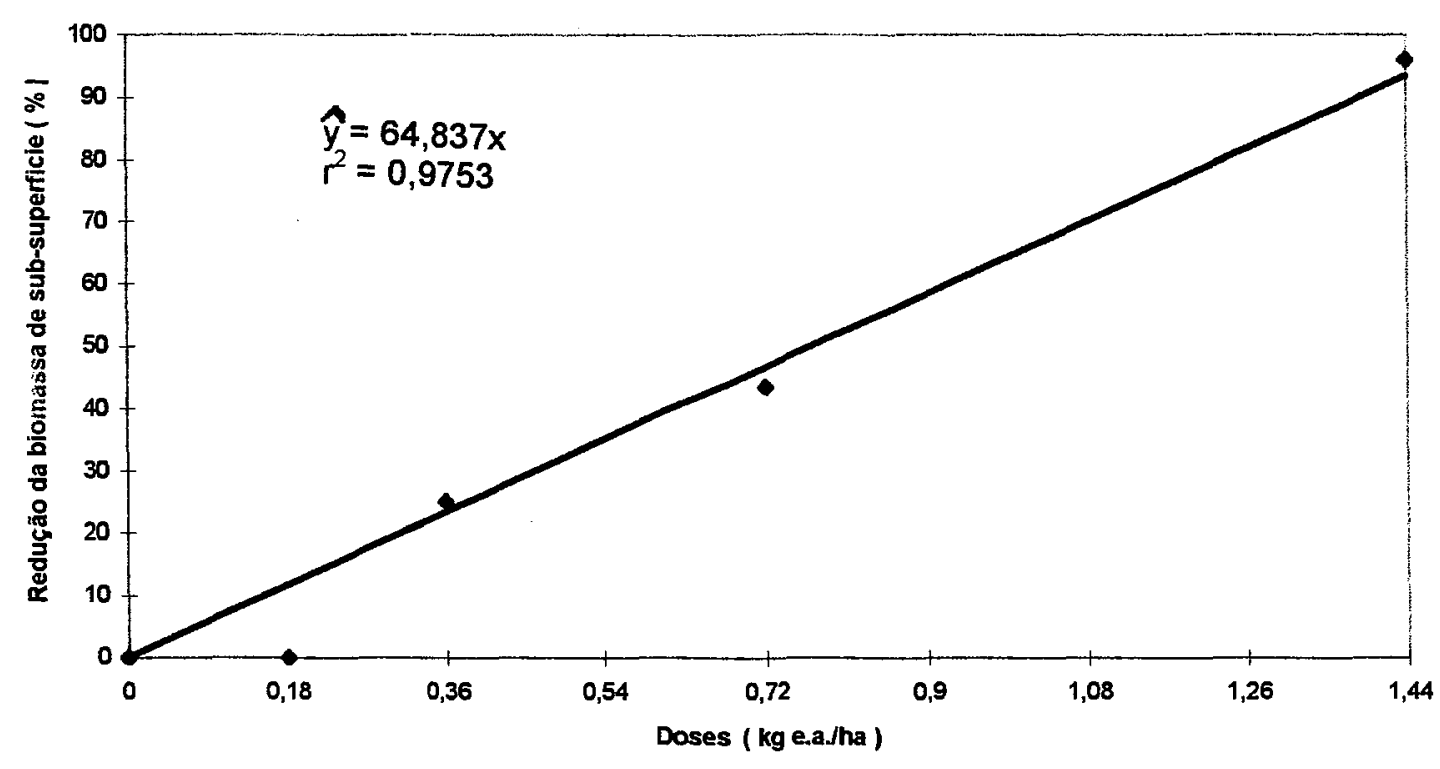

Figura 8. Efeito das doses de glyphosate sem adjuvante na redução da biomassa de subsuperficie de C. rotundus L. 75 DAA.

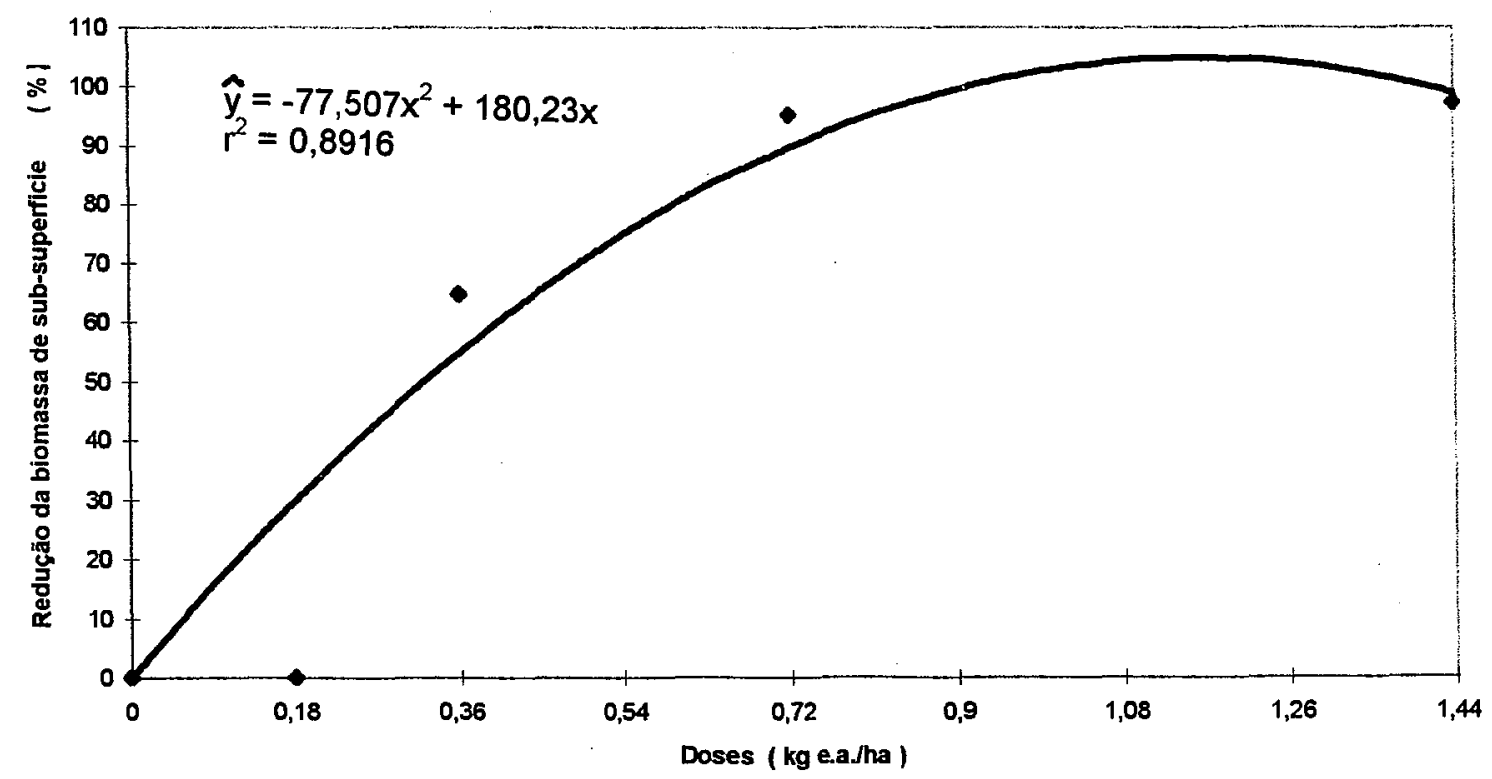

Figura 9. Efeito das doses de glyphosate com sulfato de amônio na redução da biomassa de sub-superficie de C. rotundus L. 75 DAA. 


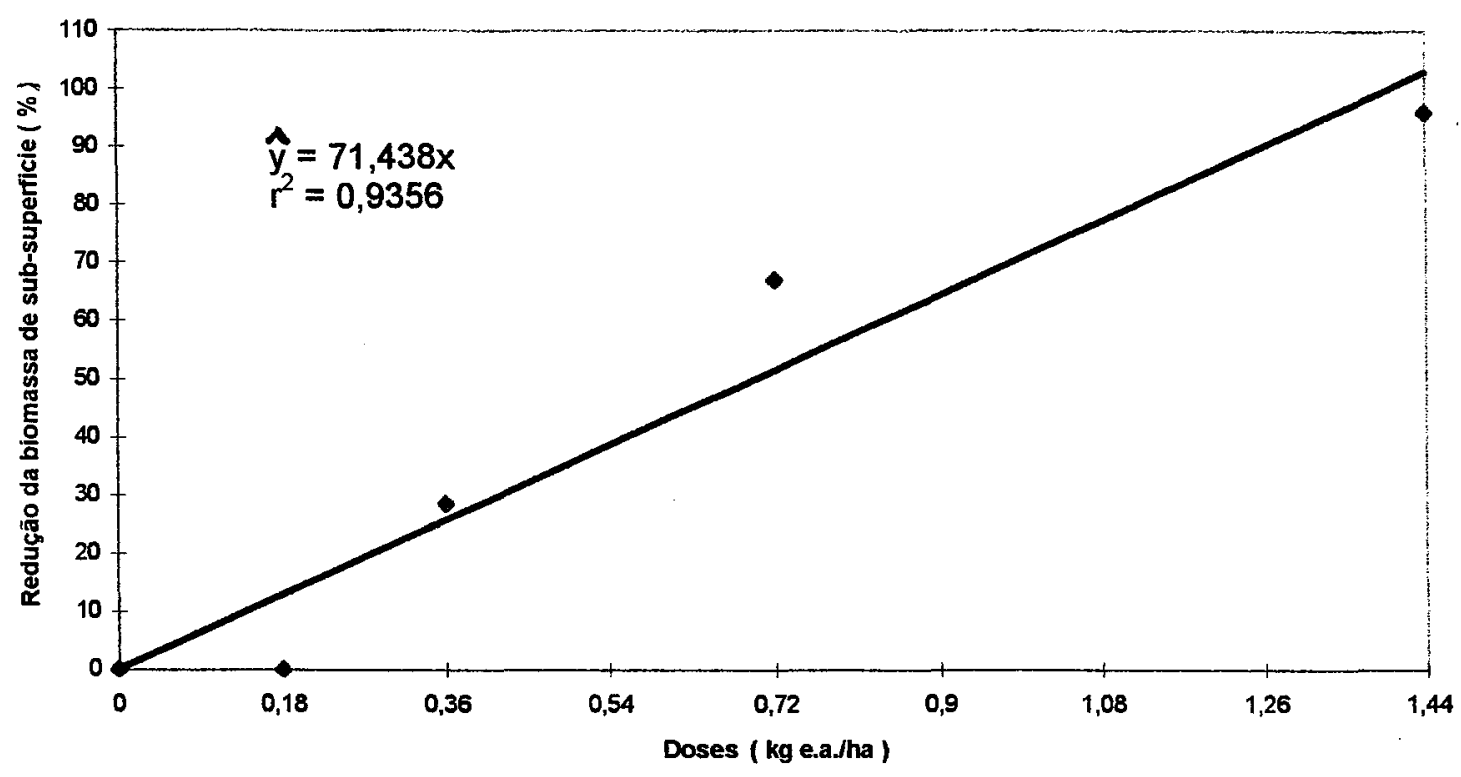

Figura 10. Efeito das doses de glyphosate com fosfato monoamônico na redução da biomassa de sub-superficie de C. rotundus L. 75 DAA.

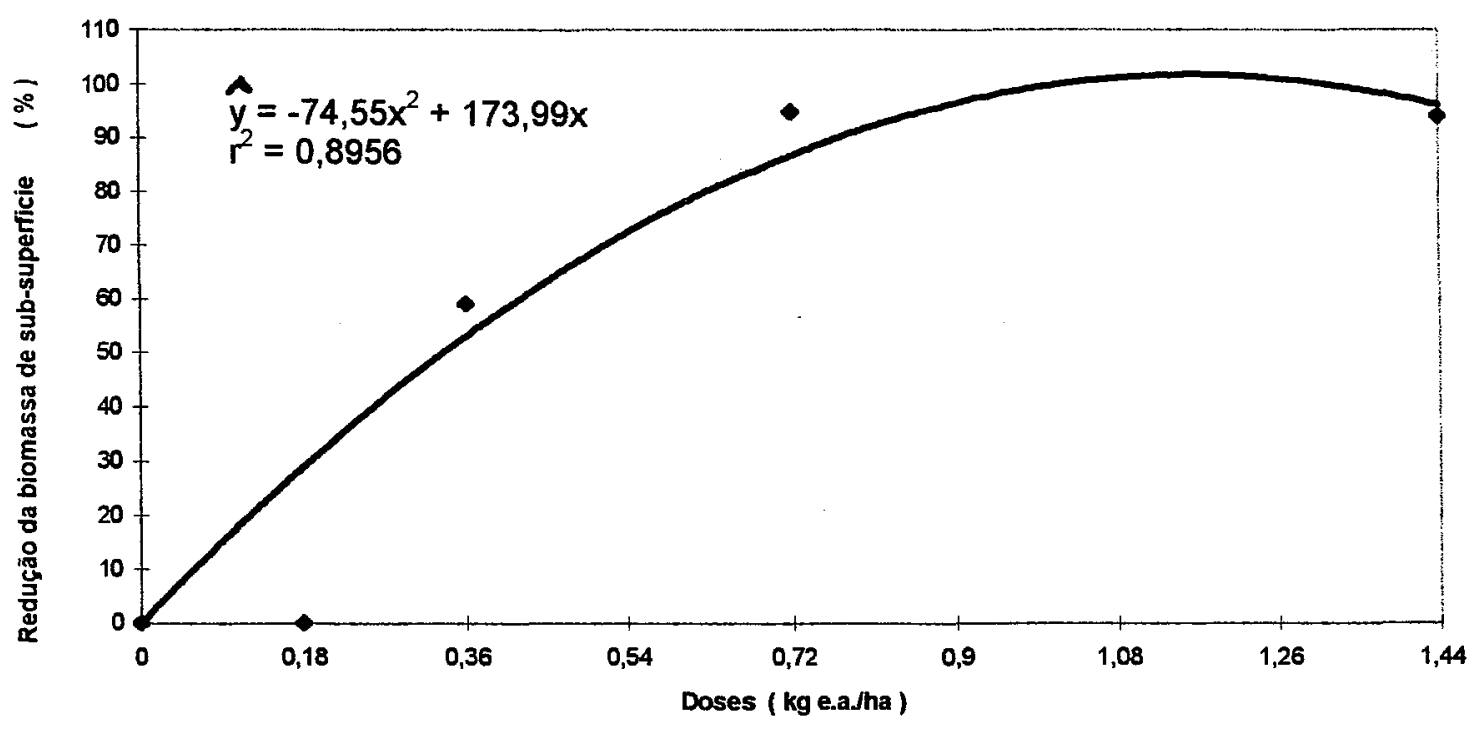

Figura 11. Efeito das doses de glyphosate com uréia na redução da biomassa de subsuperficie de $C$. rotundus $\mathrm{L}$. 75 DAA. 


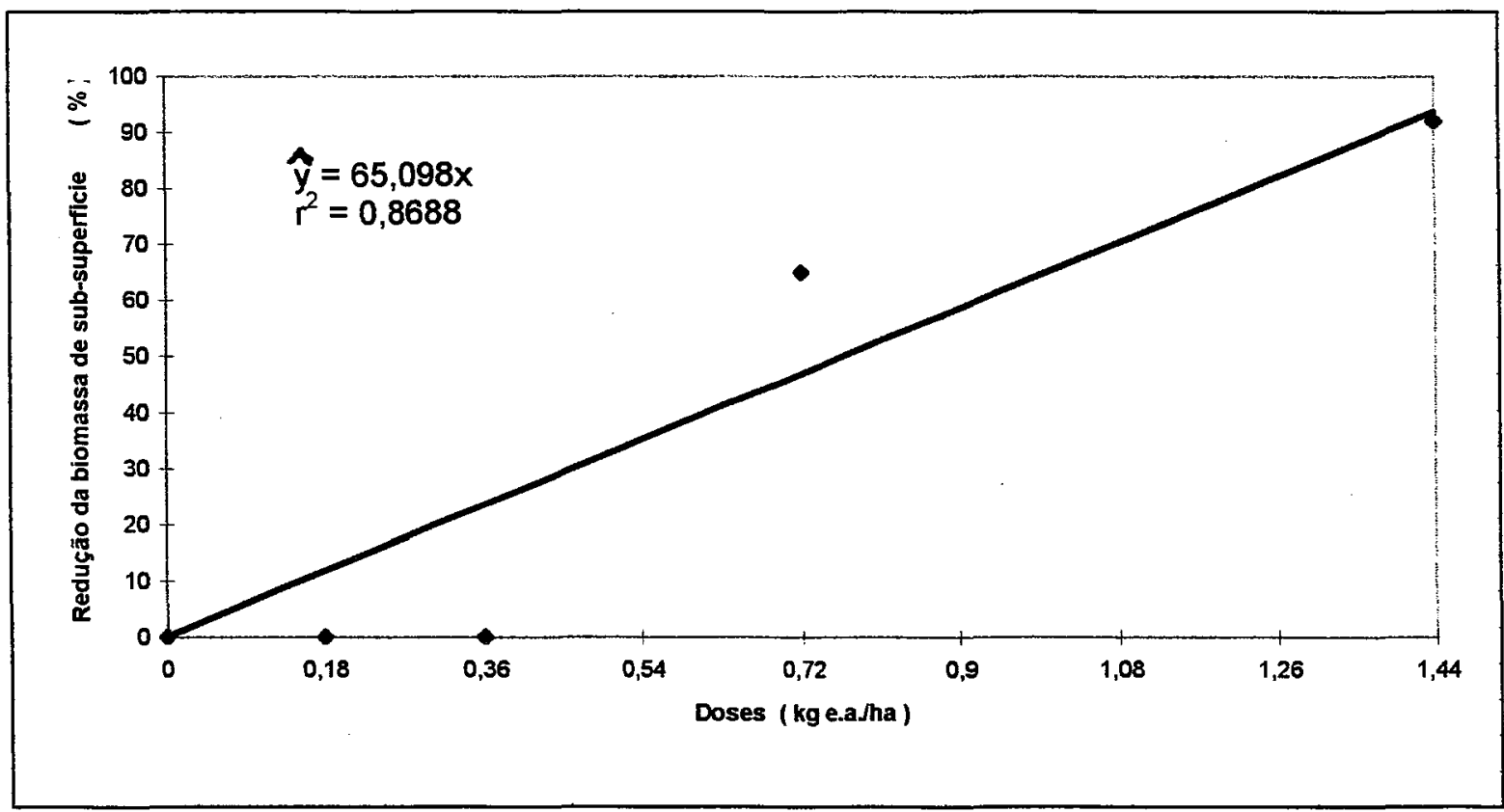

Figura 12. Efeito das doses de glyphosate com surfactante AF na redução da biomassa de sub-superficie de $C$. rotundus L. 75 DAA.

O sulfato de amônio, como mostram os resultados obtidos neste experimento, aumentou a eficácia nas doses baixas. A influência do sulfato de amônio foi tão evidente que o mesmo nível de controle foi obtido com a metade da dose de glyphosate.

Estes resultados confirmam os obtidos em outras pesquisas, tanto em C. rotundus quanto em outras espécies de plantas daninhas. A esse respeito, SUWUNNAMEK \& PARKER (1975) relatam que o controle de $C$. rotundus com $0,25 \mathrm{~kg}$ e.a./ha de glyphosate mais sulfato de amônio 2,5 ou $10,0 \mathrm{~kg} / \mathrm{ha}$ foi equivalente à obtida com 0,5 kg e.a./ha de glyphosate isolado. TURNER \& LOADER (1980), encontraram que o sulfato de amônio aumentou a fitotoxicidade do glyphosate no controle de $A$. repens em condições de campo, e que $0,25 \mathrm{~kg} / \mathrm{ha}$ de glyphosate mais $5 \%$ de sulfato de amônio foi tão 
eficiente quanto $0,5 \mathrm{~kg} / \mathrm{ha}$ de glyphosate isolado. DONALD (1988), aumentou o controle de Hordeum jubatum, adicionando $2,8 \mathrm{~kg} / \mathrm{ha}$ de sulfato de amônio a $0,56 \mathrm{~kg} / \mathrm{ha}$ de glyphosate. SALISBURY et al. (1991), relataram que o controle de capim massambará com $0,42 \mathrm{~kg} / \mathrm{ha}$ de glyphosate mais $3,33 \mathrm{~kg} / \mathrm{ha}$ de sulfato de amônio foi semelhante ao obtido com 0,84 $\mathrm{kg} / \mathrm{ha}$ de glyphosate isolado.

Os mecanismos de ação do sulfato de amônio no aumento da eficiência do glyphosate ainda não estão bem esclarecidos; no entanto, o sulfato de amônio aumentaria a absorção do glyphosate ao nível da cutícula ao impedir ou retardar a secagem da solução do herbicida pois esta fica sob os cristais de sulfato de amônio formados no resíduo da gota, independentemente do glyphosate (MacISAAC et al., 1991; NALEWAJA et al., 1992).

Outra ação que contribuirá ao efeito do sulfato de amônio poderia ser a habilidade dos cátions de amônio para incrementar a permeabilidade da membrana celular (POOVAIAH \& LEOPOLD, 1976) e diminuir o pH do apoplasto (HOFFMAN et al., 1992) promovendo um gradiente de $\mathrm{pH}$ através da membrana, o qual favorecerá a protonação das moléculas do glyphosate, tornando-as menos polares, facilitando assim sua penetração no simplasto (WADE et al., 1993).

Aliás, a formação de um complexo de glyphosate com o ion amônio do sulfato, facilita a absorção do herbicida (NALEWAJA \& MATYSIAK, 1993; THELEN et al., 1995a).

Os efeitos da uréia na eficácia do glyphosate tem sido semelhantes à do sulfato de amônio no controle do C. rotundus, ou seja, as doses de glyphosate podem 
ser reduzidas à metade com a adição deste fertilizante, sem prejuízo da eficiência do controle.

Estes resultados concordam com os obtidos por SUWUNNAMEK \& PARKER (1975), também no controle de C. rotundus. Estes autores relatam que com a adição de $10 \mathrm{~kg} / \mathrm{ha}$ de uréia a $0,25 \mathrm{~kg} / \mathrm{ha}$ de glyphosate conseguiram o mesmo nível de controle que com $0,5 \mathrm{~kg} / \mathrm{ha}$ de glyphosate isolado. Existe concordância também com os resultados de DURIGAN (1992) no controle de capim-colonião, que conseguiu reduzir a dose de $1,8 \mathrm{~kg}$ e.a./ha de glyphosate para $1,44 \mathrm{com}$ a adição de $0,2 \%$ de uréia.

O efeito favorável da uréia na absorção do glyphosate poderia ser atribuído ao rompimento das ligações éster, éter e diéter da cutina, que aparecem como redes, promovendo a maior absorção dos elementos que estiveram juntos na mesma calda, ao aumentar o espaço de entrada (YAMADA' et al., 1964).

A fraca atuação do fosfato monoamônico na eficácia do glyphosate, pode ser devida à menor quantidade de íons amônio disponíveis, como conseqüência da dose utilizada, já que em doses equivalentes mostrou ter o mesmo efeito que o sulfato de amônio e uréia (SUWUNNAMEK \& PARKER, 1975; NALEWAJA \& MATYSIAK, 1991).

O efeito negativo do surfactante AF na eficácia do glyphosate, observado neste experimento pode ser atribuída à ineficiência de seus componentes em promover a absorção do glyphosate. O surfactante AF (nome comercial Aterbane) é um condensado de álcool fenóis, mistura de isooctil fenóxi polietóxi etanol e dioctil sulfonato de sódio, surfactantes não iônico e aniônico (CARVALHO, 1989). 
Os resultados obtidos com o surfactante AF nesta pesquisa, concordam com os obtidos por diversos pesquisadores. WYRILL \& BURNSIDE (1977), constataram que os surfactantes não iônicos foram pouco eficientes no aumento da fitotoxicidade do glyphosate e os aniônicos por sua vez, foram ainda menos eficientes que os não iônicos. Observaram também que o conteúdo de oxietilenos (OE) afeta a eficácia dos surfactantes, pois, os que possuem um conteúdo relativamente alto de $\mathrm{OE}$, apresentam maior eficácia na ativação do glyphosate. De RUITER et al. (1990), encontraram que o surfactante não iônico Renex 688 , com baixo conteúdo de OE (8 unidades), reduziu a absorção do glyphosate. GASKIN \& HOLLOWAY (1992), observaram que o índice ótimo de $\mathrm{OE}$ nos surfactantes para aumentar a eficácia do glyphosate é 15 a 20 unidades, os surfactantes com baixo conteúdo de $\mathrm{OE}$ não aumentaram a absorção do glyphosate, ao contrário, diminuiram. CORET \& CHAMEL (1993), constataram que os álcoois alifáticos com 10 unidades de $\mathrm{OE}$ não aumentaram a absorção do glyphosate.

KNOCHE \& BUKOVAC (1993), encontraram que os surfactantes não iônicos, com baixo conteúdo de $\mathrm{OE}(<10$ unidades $)$, foram excelentes espalhantes, mas a absorção do glyphosate com o uso desses surfactantes foi muito baixa.

Os mecanismos de ação dos surfactantes não estão ainda bem esclarecidos. No entanto, os resultados obtidos neste experimento com o surfactante estudado poderiam ser atribuídos a seu grande efeito espalhante adesivo, que afeta uma série de fatores físico-químicos que influenciam a absorção do glyphosate. Entre eles, a rápida evaporação da água com menor tensão superficial, pois a taxa de evaporação têm uma relação linear com a área da interface da gota com a superficie da folha (KNOCHE \& BUKOVAC, 1993). A baixa mobilidade das moléculas de glyphosate no resíduo da gota seco pode diminuir a difusão das moléculas do herbicida através da cutícula 
(SCHÖENHERR \& BUKOVAC, 1970). Por sua vez, a rápida evaporação da gota e a secagem dos resíduos não higroscópicos podem limitar a hidratação da cutícula e consequentemente diminuir a absorção do glyphosate (SCHÖENHERR \& BUKOVAC, 1970). Os surfactantes com menor conteúdo de OE são menos higroscópicos (STEVENS \& BUKOVAC, 1987).

A maior área de contato entre a gota e a superficie da folha, diminui a concentração do herbicida (BOERBOOM \& WYSE, 1988), a qual têm considerável influência na absorção do glyphosate, sobretudo nas doses baixas do herbicida (GASKIN \& HOLLOWAY, 1992).

Por outro lado, é provável que o sódio contido no dioctil sulfonato de sódio, poderia ter diminuído a atividade do glyphosate devido a seu efeito antagônico (NALEWAJA \& MATYSIAK, 1991).

\subsection{Efeito do volume da calda, doses e adjuvantes na eficácia do glyphosate}

A interação do volume de calda, doses e adjuvantes na eficácia do glyphosate, 15 DAA, não foi significativa; no entanto, foram significativas as interações duplas desses fatores.

\subsubsection{Efeito da interação do volume da calda com doses de glyphosate}

Os resultados do efeito da interação do volume da calda com as doses de glyphosate, constantes na Tabela 10 e Figura 13, mostram que houve efeito do volume da calda na eficácia do glyphosate na dose baixa $(0,36 \mathrm{~kg}$ e.a./ha), pois aumentando o volume 
de calda de 150 para 300-450 1/ha, o controle diminuiu significativamente. Nas doses altas $(0,72$ e $1,44 \mathrm{~kg}$ e.a./ha) não houve efeito do volume na eficácia do glyphosate.

Tabela 10. Efeito da interação de volume de calda com doses de glyphosate, no controle de C. rotundus L., expresso em porcentagem de redução do rebrote. 15 DAA. Piracicaba, SP, 1996.

\begin{tabular}{lccc}
\hline & \multicolumn{3}{c}{ Doses de Glyphosate (D) (kg e.a./ha) } \\
\cline { 2 - 4 } Volume (V) (1/ha) & 0,36 & 0,72 & 1,44 \\
\hline 150 & $96,8^{(1)}$ a B & 99,3 a A & 99,2 a A \\
300 & 94,4 b B & 99,3 a A & 99,8 a A \\
450 & 93,3 b B & 98,5 a A & 99,3 a A \\
& & & \\
F (DxV) & & $3,1 *$ & - \\
C.V. (\%) & & 2,0 & \\
(1) Médias com a mesma letra, minúsculas nas colunas e maiúsculas nas linhas, não \\
apresentam diferença significativa segundo o teste de Tukey a 5\% de probabilidade. \\
* Significativos ao nível de 5\% de probabilidade.
\end{tabular}

Estes resultados concordam com os obtidos por STAHLMAN \& PHILLIPS (1979) que relatam maior controle do sorgo com doses baixas de glyphosate $(0,65$ e $0,84 \mathrm{~kg} / \mathrm{ha})$ quando diminuiram o volume da calda de 374 para $93 \mathrm{l} / \mathrm{ha}$; a diferença foi ainda mais evidente em água contendo sais. Também O'SULLIVAN et al. (1981) obtiveram resultados semelhantes, pois o glyphosate a $0,14 \mathrm{~kg}$ e.a./ha foi mais fitotóxico a $110 \mathrm{l} / \mathrm{ha}$ que a $220 \mathrm{1} / \mathrm{ha}$; entretanto, a $0,84 \mathrm{~kg} / \mathrm{ha}$ não houve diferenças significativas no controle de Hordeum vulgare entre os volumes baixo e alto. 


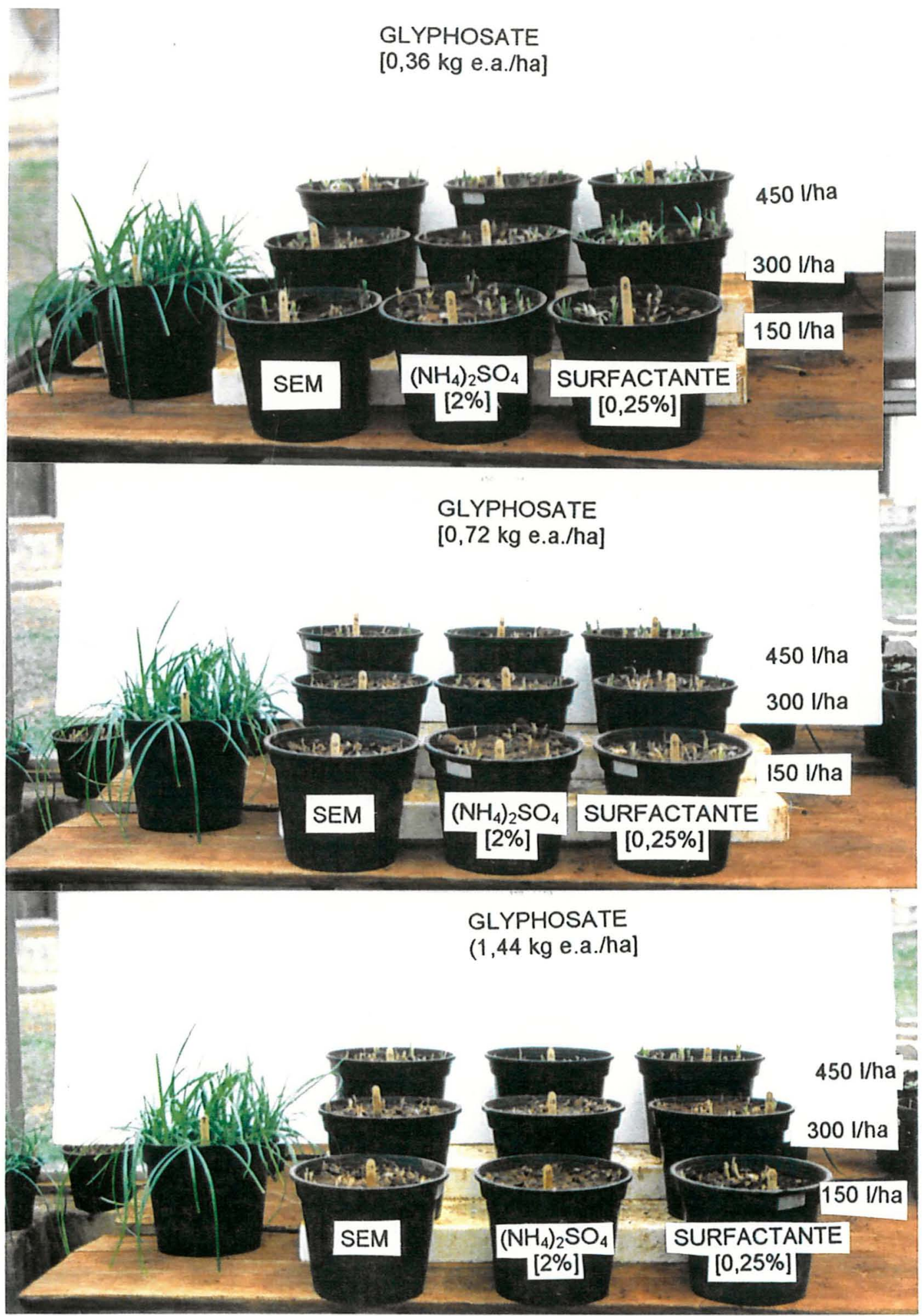

Figura 13. Efeito do volume de calda, doses e adjuvantes na redução do rebrote de Cyperus rotundus L. 15 DAA. Piracicaba, SP, 1996. 
O efeito do volume de calda na eficácia do glyphosate poderia ser atribuído à concentração do glyphosate pois este é hidrossolúvel, quando formulado na forma de isopropil amina. Numa mesma dose, diminuindo-se o volume aumenta a concentração e vice-versa. Segundo os resultados do experimento (Tabela 10), na dose de $0,36 \mathrm{~kg}$ e.a./ha as concentrações com 150,300 e 450 1/ha foram 2,$4 ; 1,2$ e $0,8 \%$; por isto, é que diminuindo o volume aumenta a concentração do herbicida e portanto o controle. Nas doses maiores não houve efeito com a diminuição do volume porque as concentrações do glyphosate mantiveram-se altas, e por isso, também o controle com as duas doses maiores $(0,72$ e $1,44 \mathrm{~kg}$ e.a. $/ \mathrm{ha})$ superaram significativamente a menor $(0,36 \mathrm{~kg}$ e.a. $/ \mathrm{ha})$.

AMBACH \& ASHFORD (1982); BUHLER \& BURNSIDE (1983), demonstraram que com o aumento da concentração do glyphosate na calda, com a aplicação da mesma dose aumenta a fitotoxicidade do herbicida. BOERBOOM \& WYSE (1988), sugerem que deve haver uma concentração ótima de glyphosate para o controle de plantas daninhas perenes e que aplicações mais ou menos concentradas que esta concentração ótima podem reduzir a absorção e translocação do herbicida, o qual é imprescindível no controle destes tipos de plantas.

\subsubsection{Efeito da interação de adjuvantes com doses de glyphosate no controle de $C$. rotundus}

$\mathrm{Na}$ Tabela 11 e Figura 13, apresentam-se os resultados da interação dos adjuvantes, sulfato de amônio e do surfactante AF com as doses de glyphosate 0,36; 0,72 e $1,44 \mathrm{~kg}$ e.a./ha, no controle de $C$. rotundus, média de aplicação nos três volumes de 
calda $(150,300$ e $450 \mathrm{l} / \mathrm{ha})$. Os resultados mostram que o sulfato de amônio elevou significativamente a eficácia do glyphosate no controle de $C$. rotundus, na dose baixa $(0,36$ $\mathrm{kg}$ e.a./ha) mas não nas doses altas $(0,72$ e $1,44 \mathrm{~kg}$ e.a./ha).

Tabela 11. Efeito da interação de adjuvantes com doses de glyphosate, no controle de $C$. rotundus L., expresso em porcentagem de redução do rebrote. 15 DAA. Piracicaba, SP, 1996.

\begin{tabular}{lccc}
\hline & \multicolumn{3}{c}{ Doses de Glyphosate (D) (kg e.a./ha) } \\
\cline { 2 - 4 } Adjuvante (A) & 0,36 & 0,72 & 1,44 \\
\hline Sem & $95,3^{(1)}$ b B & 99,6 a A & 99,9 a A \\
Sulfato de amônio & 98,2 a A & 99,5 a A & 99,3 a A \\
Surfactante AF & 91,2 c B & 97,9 a A & 99,0 a A \\
& & & \\
F (AxD) & & $9,7 * *$ & \\
C.V. (\%) & - & 2,3 & - \\
\hline
\end{tabular}

(1) Médias com a mesma letra, minúsculas nas colunas e maiúsculas nas linhas, não apresentam diferença significativa segundo o teste de Tukey a $5 \%$ de probabilidade.

* Significativos ao nível de $1 \%$ de probabilidade.

O surfactante AF, diminuiu significativamente a eficácia do glyphosate na dose mais baixa $(0,36 \mathrm{~kg}$ e.a./ha); mas nas doses maiores, a diminuição não foi significativa.

Com a adição de sulfato de amônio na dose $0,36 \mathrm{~kg}$ elevou-se o controle ao mesmo nível das doses maiores $(0,72$ e $1,44 \mathrm{~kg}$ e.a./ha). No entanto, nos outros tratamentos com glyphosate isolado e glyphosate com surfactante $\mathrm{AF}$ as doses maiores superaram significativamente a menor e não houve diferença entre si. 
Esses resultados confirmam os efeitos destes adjuvantes na eficácia do glyphosate, obtidos no primeiro experimento deste trabalho.

\subsubsection{Efeito da interação de adjuvantes com o volume de calda, no controle de C. rotundus}

Os resultados da interação dos adjuvantes sulfato de amônio e surfactante AF com os volume de calda 150; 300 e 450 1/ha, constantes na Tabela 12, mostram que com sulfato de amônio resultou em controle igual com 150, 300 e 450 1/ha de calda.

O surfactante $\mathrm{AF}$ reduziu o controle a 300 e 450 1/ha, a redução foi significativa com relação ao menor volume 150 1/ha e com relação aos outros tratamentos, nos mesmos volumes. Não teve influência significativa dentro do volume de $150 \mathrm{l} / \mathrm{ha}$.

Os resultados concordam com os obtidos por O'SULLIVAN et al. (1981), que relataram a menor eficácia do glyphosate ao incrementar o volume de calda, sobretudo nas doses baixas. As doses maiores superaram a diferença entre baixo e altos volumes. A adição de sulfato de amônio mais Agral elevou o controle da dose baixa de glyphosate com volume alto. Outros surfactantes como Renex 36 e Citoweet plus reduziram a eficácia do glyphosate 
Tabela 12. Efeito da interação de adjuvantes com volume de calda, no controle de $C$. rotundus L., expresso em porcentagem da redução de rebrote. 15 DAA. Piracicaba, SP, 1996.

\begin{tabular}{lccc}
\hline & \multicolumn{3}{c}{ Adjuvante (A) } \\
\cline { 2 - 4 } Volume (V) & SEM & $\begin{array}{c}\text { SULFATO DE } \\
\text { AMÔNIO }\end{array}$ & $\begin{array}{c}\text { SURFACTANTE } \\
\text { Af }\end{array}$ \\
\hline 150 & $98,7^{(1)}$ a A & 98,6 a A & 98,0 a A \\
300 & 98,1 a A & 99,5 a A & 95,8 b B \\
450 & 98,0 a A & 98,8 a A & 94,3 b B \\
& & & \\
F (AxV) & & $3,7^{* *}$ & - \\
C.V. (\%) & & 2,0 & - \\
(1) Médias com a mesma letra, minúsculas nas colunas e maiúsculas nas linhas, não \\
apresentam diferença significativa segundo o teste de Tukey a 5\% de probabilidade. \\
** Significativos ao nível de 1\% de probabilidade.
\end{tabular}

\subsection{Efeito dos sais e dos adjuvantes na eficácia do glyphosate}

Os resultados da interação dos sais, cloreto de cálcio, cloreto de magnésio, bicarbonato de sódio, sulfato ferroso e sulfato de zinco, com os adjuvantes: surfactante $\mathrm{AF}$, sulfato de amônio, fosfato monoamônico e uréia, na eficácia do glyphosate a $0,18 \mathrm{~kg}$ e.a./ha apresentados na Tabela 13 e Figura 14, mostram que todos os sais foram antagônicos, reduziram significativamente a eficácia do glyphosate; o cloreto de cálcio 
reduziu $65,2 \%$; o cloreto de magnésio $33,8 \%$; o bicarbonato de sódio $47,9 \%$; o sulfato ferroso $90,1 \%$ e o sulfato de zinco $99,5 \%$.

Tabela 13. Efeito da interação de sais da calda com adjuvantes, na eficácia do glyphosate $(0,18 \mathrm{~kg}$ e.a. $/ \mathrm{ha})$, expresso em porcentagem de redução do peso da matéria fresca em relação a testemunha sem aplicação em sorgo granifero. 10 DAA. Piracicaba, SP, 1996.

\begin{tabular}{|c|c|c|c|c|c|c|}
\hline \multirow{3}{*}{ Adjuvantes (A) } & \multicolumn{6}{|c|}{ Sais (S) (mM) } \\
\hline & Água & $\mathrm{CaCl}_{2}$ & $\mathrm{MgCl}_{2}$ & $\mathrm{NaHCO}_{3}$ & $\mathrm{FeSO}_{4}$ & $\mathrm{ZnSO}_{4}$ \\
\hline & desmin. & 25 & 25 & 50 & 10 & 10 \\
\hline Sem & $75,5^{(1)}$ a $\mathrm{A}$ & 26,3 c B & $50,0 \mathrm{cB}$ & 39,4 b B & $7,1 \mathrm{bc} \mathrm{C}$ & $0,4 \mathrm{c} \mathrm{C}$ \\
\hline Surfactante AF & 74,4 a $\mathrm{A}$ & $12,9 \mathrm{c} \mathrm{B}$ & 72,9 abc $\mathrm{A}$ & 73,3 a $\mathrm{A}$ & $1,1 \subset \mathrm{C}$ & $11,6 \mathrm{~b} \mathrm{BC}$ \\
\hline Sulfato de amônio & 86,8 a $\mathrm{A}$ & 78,5 a A & 83,6 a $\mathrm{A}$ & 84,5 a $A$ & $6,9 \mathrm{bc} \mathrm{B}$ & 77,8 a $\mathrm{A}$ \\
\hline Fosfato monoamônico & 83,9 a $\mathrm{A}$ & $74,6 \mathrm{ab} A$ & $73,8 \mathrm{ab} \mathrm{A}$ & 81,9 a $\mathrm{A}$ & $35,2 \mathrm{a} \mathrm{B}$ & 71,3 a $A$ \\
\hline Uréia & 83,4 a $\mathrm{A}$ & $52,5 \mathrm{~b} \mathrm{BC}$ & 56,2 bc $B$ & 80,6 a $\mathrm{A}$ & $17,7 \mathrm{ab} D$ & 29,4 b CD \\
\hline$F(A \times S)^{(2)}$ & & & $8,3^{* *}$ & ------- & -------------. & - \\
\hline C.V. $(\%)$ & - & - & 15,4 & --- & --- & -- \\
\hline $\begin{array}{l}\text { (1) Médias com a } \\
\text { apresentam diferen } \\
\text { (2) Dados transform }\end{array}$ & . & $\sqrt{x / 100}$ & ste & se & bi & \\
\hline
\end{tabular}

Nos tratamentos com água desmineralizada, não houve diferenças significativas de controle entre glyphosate com adjuvantes e glyphosate isolado. Dos adjuvantes testados, sulfato de amônio e fosfato monoamônico foram os mais eficientes na superação do efeito antagônico dos sais de cálcio, magnésio, sódio e zinco. 


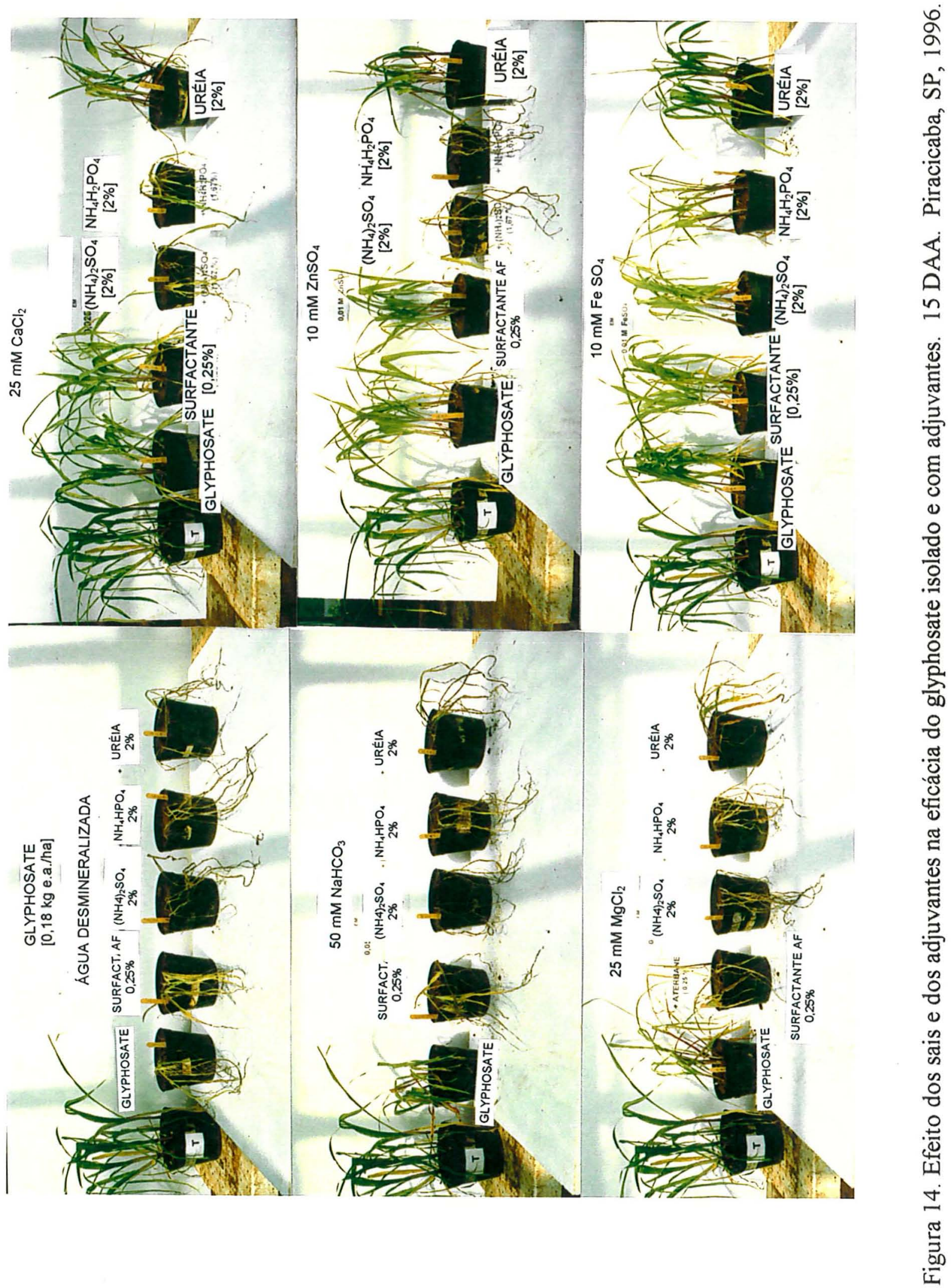


Ambos adjuvantes elevaram significativamente a eficácia do glyphosate e os níveis de controle não diferiram dos obtidos em água desmineralizada. $\mathrm{O}$ fosfato monoamônico, aliás, superou significativamente o antagonismo do $\mathrm{Fe}^{++}$, mas o nível de controle ainda foi baixo.

A uréia foi menos eficiente para superar o antagonismo dos sais, exceto para sódio, que aumentou significativamente a eficácia do glyphosate com um nível de controle equivalente ao apresentado com água desmineralizada. Superou também significativamente o antagonismo do cálcio e do zinco, mas os níveis de controle foram baixos.

O surfactante AF foi o menos eficiente dos adjuvantes testados, só superando o antagonismo do sódio com um nível de controle significativamente igual a seu correspondente, na água desmineralizada.

A redução da eficácia do glyphosate pelos sais, observada neste experimento, concordam com os resultados de SANDBERG et al. (1978), que relataram a redução da fitotoxicidade do glyphosate em Ipomoea purpurea L., pelo cálcio quando usaram concentrações $0,0025-0,04 \mathrm{M}$ de $\mathrm{CaCl}_{2}$ em volumes de calda de 375 e 750 l/ha. STAHLMAN \& PHILLIPS (1979) trabalhando com sorgo granífero, concluíram que o ferro e aluminio foram os que mais reduziram a atividade do glyphosate, seguidos por cálcio e zinco e por magnésio. No entanto, segundo estes autores, sódio e potássio não afetaram a ação do glyphosate. Esta resposta do sódio, discorda com os resultados encontrados no presente experimento e, provavelmente, é devida a concentração muito mais baixa de sódio (10 $\mathrm{mM}$ de $\mathrm{NaCl}$ ) que estes pesquisadores usaram, sendo seu efeito superado pela maior concentração do glyphosate $(0,8 \mathrm{~kg} / \mathrm{ha})$. BUHLER \& BURNSIDE (1983), em Avena sativa, 
relatam que o glyphosate foi menos fitotóxico que em água destilada, quando foi aplicado em soluções de $10 \mathrm{mM}_{\text {de }} \mathrm{CaCl}_{2}, \mathrm{FeSO}_{4}, \mathrm{Fe}_{2}\left(\mathrm{SO}_{4}\right)_{3}, \mathrm{MgSO}_{4}, \mathrm{NaHCO}_{3}, \mathrm{NaCO}_{3}$ e $\mathrm{ZnSO}_{4}$.

Os resultados deste experimento concordam também com os de NALEWAJA \& MATYSIAK (1991), que relatam o antagonismo da fitotoxicidade do glyphosate pelos sais de ferro, zinco, cálcio, magnésio, sódio em trigo; NALEWAJA \& MATYSIAK (1992a), observaram que o cloreto de cálcio foi antagônico à fitotoxicidade do glyphosate em trigo, girassol, soja e Kochia scoparia. THELEN et al. (1995a,b) trabalhando

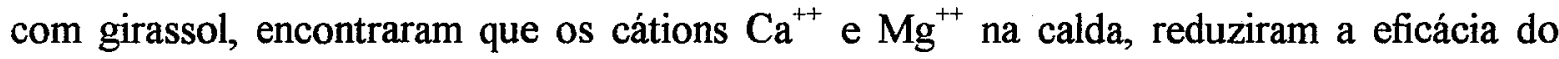
glyphosate.

A diminuição da eficácia do glyphosate pelos cátions contidos na água de pulverização foi atribuída a formação de complexos insolúveis das moléculas de glyphosate com os cátions da solução e a diferença do antagonismo entre os cátions, poderia ter relação com a habilidade destes cátions de complexar ou associar-se com o glyphosate (O'SULLIVAN et al., 1981; NALEWAJA \& MATYSIAK, 1991). Recentes estudos com ressonância magnética nuclear, mostraram que efetivamente o $\mathrm{Ca}^{++} \mathrm{e} \mathrm{Mg}^{++}$ligam-se tanto ao grupo carboxilo quanto ao grupo fosfonado da molécula de glyphosate, formando um quelato. Aliás, na presença do excesso de $\mathrm{Ca}++$, este cátion substitui a IPA (Isopropil amina) do grupo fosfonado da molécula de glyphosate, formando o quelato Ca-glyphoste pouco solúvel (THELEN et al., 1995a).

A suspensão do efeito antagônico dos cátions sobre a eficácia do glyphosate, foi explicado pela reação do ânion sulfato com o cálcio para formar sulfato de cálcio que é pouco solúvel, diminuindo o cálcio disponível para ligar-se à moléculas do 
glyphosate. A adição de ácido sulfúrico à calda diminuiu ou eliminou o efeito antagônico dos cátions (BUHLER \& BURNSIDE, 1983).

Os resultados obtidos com sulfato de amônio e fosfato monoamônico, na supressão do antagonismo dos sais concorda com os obtidos por NALEWAJA \& MATYSIAK (1991), que relatam que os ácidos sulfúrico, fosfórico e cítrico e seus sais superaram o antagonismo do bicarbonato de sódio e cloreto de cálcio. $\mathrm{O}$ cátion amônio não foi antagônico, ao contrário, aumentou a ação do glyphosate. O sulfato de amônio superou o antagonismo do bicarbonato de sódio e do cloreto de cálcio e muito pouco do sulfato férrico. $O$ fosfato de amônio superou o antagonismo do bicarbonato de sódio, cloreto de cálcio e parcialmente do sulfato férrico.

Outro mecanismo de supressão do antagonismo dos sais pelo sulfato de amônio e fosfato de amônio foi explicado por NALEWAJA \& MATYSIAK (1991) que sugeriram que o cátion amônio poderia competir com o cálcio do complexo cálcioglyphosate e forma amônio-glyphosate que teria a mesma eficácia herbicida que a isopropilamina, superando assim o antagonismo e aumentando a eficácia do glyphosate. Esta hipótese foi confirmada por THELEN et al. (1995a), que através da ressonância magnética nuclear determinaram que $\mathrm{NH}_{4}{ }^{+}$complexa diretamente com a molécula de glyphosate semelhante ao $\mathrm{Ca}^{++}$; e que o amônio compete efetivamente com o cálcio para ligar-se à molécula de glyphosate; assim, a substituição do cálcio pelo amônio resulta numa forma de glyphosate de mais rápida absorção. A formação do complexo $\mathrm{NH}_{4}$-glyphosate e a remoção do $\mathrm{Ca}^{++}$da solução pelo conjugado ânion sulfato parecem ser as bases para reversão do antagonismo da absorção do glyphosate. 


\subsection{Efeito da qualidade da água de diferentes fontes e dos adjuvantes na eficácia do glyphosate}

As características das águas das fontes testadas neste experimento apresentam-se na Tabela 5.

Os resultados do efeito da qualidade da água coletada de torneira (água potável), da represa, do rio Piracicaba, de manancial e subterrânea, na eficácia do glyphosate isolado e com adjuvantes, constantes na Tabela 14 e Figura 15, mostram que somente a qualidade da água subterrânea diminuiu significativamente a eficácia do glyphosate e que todos os adjuvantes compensaram o efeito.

Tabela 14. Efeito da qualidade da água de diferentes fontes na eficácia do glyphosate $(0,18$ $\mathrm{kg}$ e.a./ha) isolado e com adjuvantes, expresso em porcentagem de controle de sorgo granifero. 10 DAA. Piracicaba, SP, 1996.

\begin{tabular}{|c|c|c|c|c|c|c|}
\hline \multirow[b]{2}{*}{ Adjuvantes (A) } & \multicolumn{6}{|c|}{ Fontes de água $(\mathrm{F})$} \\
\hline & Água desm. & $\begin{array}{l}\text { Água } \\
\text { potável }\end{array}$ & Represa & Rio & $\begin{array}{c}\text { Manan- } \\
\text { cial }\end{array}$ & $\begin{array}{c}\text { Água } \\
\text { subterrânea }\end{array}$ \\
\hline Sem & $89,0^{(1)}$ a A & 88,0 aA & 88,0 aA & $88,3 \mathrm{aA}$ & 88,0 aA & $74,8 \mathrm{~b} \mathrm{~B}$ \\
\hline Sulfato de amônio & 89,0 a $A$ & $87,3 \mathrm{aA}$ & 77,8 aA & $82,0 \mathrm{aA}$ & $88,5 \mathrm{aA}$ & $88,0 \mathrm{a} \mathrm{A}$ \\
\hline Fosf. monoamônico & 80,8 a $A$ & $86,3 \mathrm{aA}$ & $87,8 \mathrm{aA}$ & $87,8 \mathrm{aA}$ & $87,3 \mathrm{aA}$. & $85,0 \mathrm{abA}$ \\
\hline Uréia & 87,0 a $A$ & 88,3 aA & $87,0 \mathrm{aA}$ & $79,0 \mathrm{aA}$ & $86,5 \mathrm{aA}$ & 88,8 a A \\
\hline Ácido cítrico & 91,0 a $A$ & $87,0 \mathrm{aA}$ & $86,0 \mathrm{aA}$ & 87,0 aA & $91,0 \mathrm{aA}$ & $80,3 \mathrm{abA}$ \\
\hline $\mathrm{F}(\mathrm{AxF})$ & - & - & - & $1,8^{*}$ & ---------- & -- \\
\hline C.V. $(\%)$ & 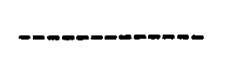 & ----------- & 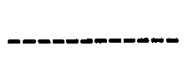 & 7,2 & 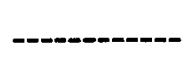 & ------- \\
\hline
\end{tabular}




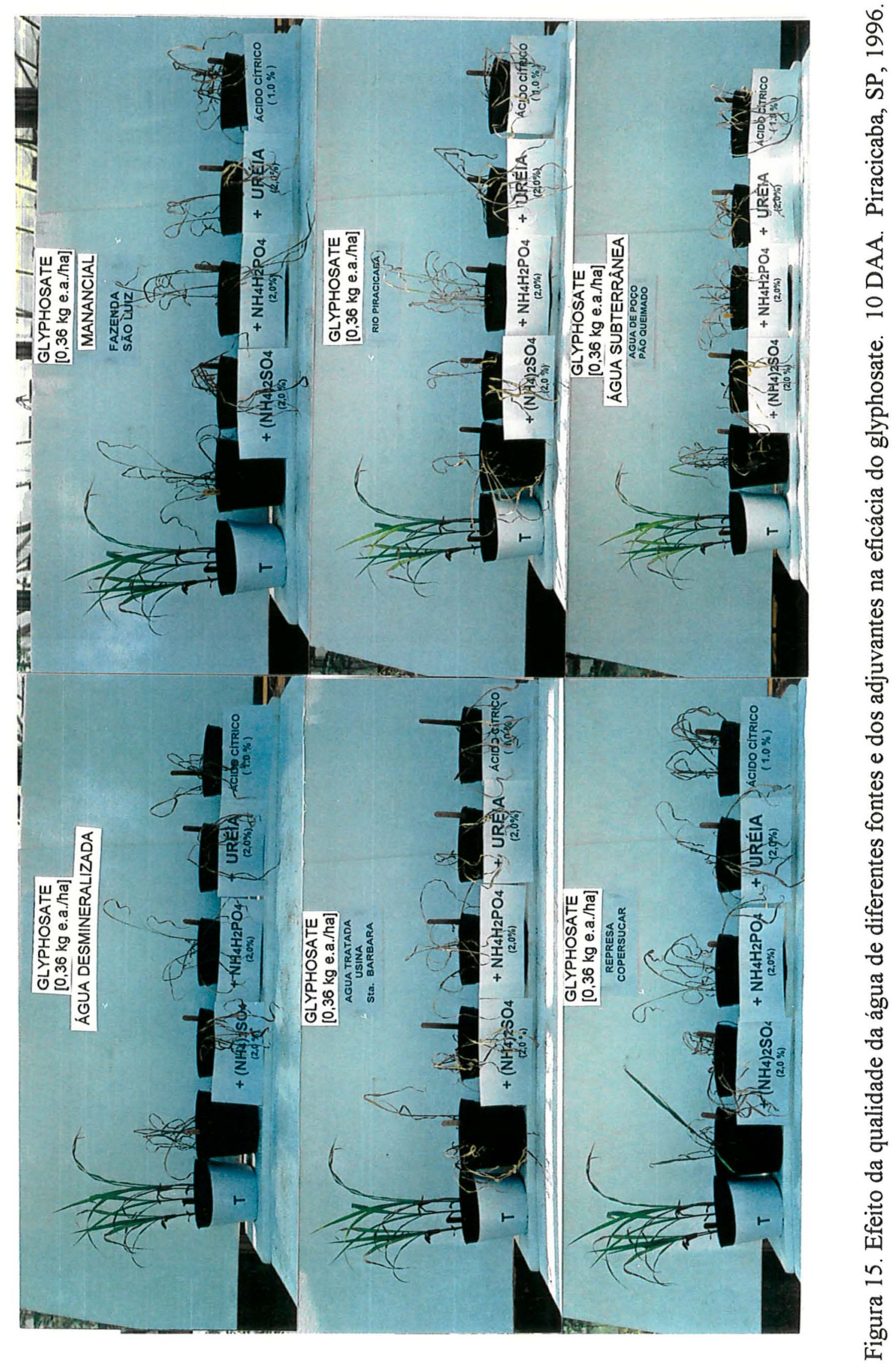


A qualidade da água da torneira, represa, rio e manancial não afetaram a eficácia do glyphosate, sendo o controle o mesmo que com água desmineralizada. A diminuição da eficácia do glyphosate usando água subterrânea pode-se atribuir ao antagonismo dos sais contidos: $102 \mathrm{mg} / 1$ de cálcio, $20 \mathrm{mg} / \mathrm{l}$ de sódio e $3,4 \mathrm{mg} / \mathrm{l}$ de magnésio (Tabela 5) e a baixa dose do herbicida. Entretanto, o efeito da água proveniente de outras fontes foi provavelmente devido a seu baixo conteúdo de sais e a presença considerável do anion sulfato (Tabela 5). Estes resultados concordam com os de BUHLER \& BURNSIDE (1983), que encontraram fontes de água com concentrações de $\mathrm{CaCl}_{2}$ acima de $2 \mathrm{mM}$ (> 80 $\mathrm{mg} / \mathrm{l}$ ) e maiores que zero para o sódio e magnésio, as quais reduziram a atividade do glyphosate. 


\section{CONCLUSÕES}

Os resultados obtidos nas condições do presente trabalho, permitem as seguintes conclusões:

- O sulfato de amônio e a uréia aumentaram a eficácia das doses baixas de glyphosate no controle de Cyperus rotundus $\mathrm{L}$.

- A adição de sulfato de amônio a $2,0 \% \mathrm{p} / \mathrm{v}$ ou uréia a $2,0 \% \mathrm{p} / \mathrm{v}$ na calda de aplicação permitiu reduzir à metade a dose $1,44 \mathrm{~kg}$ e.a./ha de glyphosate, mantendo . o mesmo controle da rebrota da parte epígea e da biomassa de sub-superficie de $C$. rotundus.

- O sulfato de amônio superou o efeito antagônico que os sais de cálcio, magnésio, sódio e zinco exercem na ação do glyphosate, mas não o antagonismo dos sais de ferro.

- A uréia superou o antagonismo do sódio sobre a ação do glyphosate, mas não a dos sais de cálcio, magnésio, ferro e zinco. 
- O surfactante, mistura de isooctil fenoxi poli etóxi etanol e dioctil sulfonato de sódio, reduziu a eficácia das doses médias e baixas do glyphosate, no controle de C. rotundus.

- A redução do volume de calda, aumentou a eficácia das doses baixas de glyphosate, no controle de C. rotundus.

- Os sais de cálcio, magnésio, sódio, ferro e zinco na calda de aplicação reduziram a eficácia do glyphosate em sorgo granífero, na seguinte ordem de intensidade: $\mathrm{Zn}^{++}=\mathrm{Fe}^{++}>\mathrm{Ca}^{++}=\mathrm{Mg}^{++}=\mathrm{Na}^{+}$.

- A água das fontes não afetaram a eficácia do glyphosate em sorgo granífero, com exceção da água subterrânea que a diminuiu. 


\section{REFERÊNCIAS BIBLIOGRÁFICAS}

AMBACH, R.M.; ASHFORD, R. Effects of variations in drop makeup on the phytotoxicity of glyphosate. Weed Science, v.30, p.221-4, 1982.

ARJONA-BERRAL, A.; MESA-GARCIA, J.; GARCIA-TORRES, L. Distribution of ${ }^{14} \mathrm{C}$ glyphosate in legumes parasitised by Orobanche crenata. Weed Research, v.30, p.53$9,1990$.

BOERBOOM, C.M.; WYSE, D. Influence of ghyphosate concentration on glyphosate absortion and translocation in canada thistle (Cirsium arvense). Weed Science, v.36, p.291-5, 1988.

BRECKE, B.J.; DUKE, W.B. Effect of glyphosate on intact bean plants (Phaseolus vulgaris L.) and isolated cells. Plant Physiology, v.66, p.656-9, 1980.

BUHLER, D.D.; BURNSIDE, O.C. Effect of water quality carrier volume, and acid on glyphosate phytotoxicity. Weed Science, v.31, p.163-9, 1983.

BUKOVAC, M.J.; PETRACEK, P.D.; FADER, R.G.; MORSE, R.D. Sorption of organic compounds by plant cuticles. Weed Science, v.38, p.289-98, 1990.

CAMACHO, R.F.; MOSHIER, L.J. Absorption, translocation and activity of CGA-136872, DPX-V9360, and glyphosate in rhizome of johnsongrass (Sorghum halepense). Weed Science, v.39, p.354-7, 1991. 
CARVALHO, J.C. Fatores que influenciam a eficácia dos herbicidas aplicados em pósemergência no controle de espécies de Ipomoea e outras plantas daninhas dicotiledôneas na cultura da soja (Glycine max L. Merrill). Piracicaba, SP, 1989. 135p. Dissertação (Mestrado) - Escola Superior de Agricultura "Luiz de Queiroz", Universidade de São Paulo.

CASELEY, J.C.; COUPLAND, D. Environmental and plant factors affecting glyphosate uptake, movement and activity. In: GROSSBARD, E.; ATKINSON, D., ed. The herbicide glyphosate. London: Butterworths and Co., 1985. p.93-123.

CHASE, R.L.; APPLEBY, A.P. Effects of humidity and moisture stress on glyphosate control of Cyperus rotundus L. Weed Research, v.19, p.207-46, 1979.

COLE, D.J. Mode of action of glyphosate - a literature analysis. In: GROSSBARD, E.; ATKINSON, D., ed. The Herbicide Glyphosate. London: Butterworths, 1985. p.48-74.

CONN, J.S.; DECK, R.E. Bluejoint reedgrass (Calamagostris canadensis) control with glyphosate and additives. Weed Technology, v.5, p.521-4, 1991.

CONN, J.S.; DECK, R.E. Optimal glyphosate application time for control of foxtail barley (Hordeum jubatum). Weed Technology, v.9, p.267-9, 1995.

CORET, J.M.; CHAMEL, A.R. Influence of some monionic surfactants on water sorption by isolated tomato fruit cuticles in relation to cuticular penetration of glyphosate. Pesticide Science, v.38, p.27-32, 1993.

DEUBER, R.; FORSTER, R. Controle da tiririca (Cyperus rotundus L.) com glyphosate. Revista de Agricultura, v.52, p.183-90, 1977. 
De RUITER, H.; UFFING, A.J.M.; MEINEN, E.; RUINS, A. Influence of surfactants and plant species on leaf retention of spray solutions. Weed Science, v.38, p.567-72, 1990.

DEVINE, M.D.; HALL, L.M. Implications of sucrose transport mechanism for the translocation of herbicides. Weed Science, v.38, p.299-304, 1990.

DOLL, J.D.; PIEDRAHITA, W. Effect of glyphosate on the sprouting of Cyperus rotundus L. tuber. Weed Research, v.22, p.123-8, 1982.

DONALD, W.W. Established foxtail barley, Hordeum jubatum, control with glyphosate plus ammonium sulfate. Weed Technology, v.2, p.364-8, 1988.

DURIGAN, J.C. Efeito de adjuvantes na calda e do estádio de desenvolvimento das plantas, no controle do capim colonião (Panicum maximum) com glyphosate. Planta Daninha, v.10, p.39-44, 1992.

GASKIN, R.E., HOLLOWAY, P.J. Some physiochemical factors influencing foliar uptake enhancement of glyphosate-mono (isopropylammonium) by polyoxyethilene surfactants. Pesticide Science, v.34, p. 195-206, 1992.

GOUGLER, J.A.; GEIGER, D.R. Uptake and distribution of N-phosphonomethyl glycine in sugar beet plants. Plant Physiology, v.68, p.668-72, 1981.

GUIMARÃES, S.C. Influência da idade de corte e de aditivos na ação do glyphosate sobre a tiririca (Cyperus rotundus L.). Viçosa, 1981. 87p. Dissertação (Mestrado) Universidade Federal de Viçosa.

GREN, J.M.; GREN, J.H. Surfactant structure and concentration strongly affect rimsulfuron activity. Weed Technology, v.7, p.633-40, 1993. 
GRONWALD, J.W.; JOURDAN, S.W.; WYSE, D.L.; SOMERS, D.A.; MAGNUSSON, M.U. Effect of ammonium sulfate on absorption of Imazethapyr by quackgrass (Elytrigia repens) and maize (Zea mays) cell suspension cultures. Weed Science, v.41, p-325-34, 1993.

HADERLIE, L.C.; WIDHOLM, J.M.; SLIFE, F.W. Effect of glyphosate on carrot and tobacco cells. Plant Physiology, v.60, p.40-3, 1977.

HARKER, K.N. Effects of various adjuvants on sethoxydin activity. Weed Technology, v.6, p.865-70, 1992.

HARKER, K.N. Ammonium sulfate effects on the activity of herbicides for selective grass control. Weed Technology, v.9, p.260-6, 1995.

HARKER, K.N.; O'SULLIVAN, P.A. Ammonium sulfate enhances control of annual grass weeds in canola (Brassica campestris) with sethoxydin. Canadian Journal of Plant Science, v.68, p.1087-93, 1988.

HESS, D.F.; FOLK, R.H. Herbicide deposition on leaf surfaces. Weed Science, v.38, p.280-8, 1990.

HOFFMANN, B.; PLÄNKER, R.; MENGEL, K. Measurenment of $\mathrm{pH}$ in the apoplast of sunflower leaves by means of fluorescence. Physiologia Plantarum, v.84, p.146-53, 1992.

HOLlOWAY, P.J. Structure and chemistry of plant cuticles. Pesticide Science, v.37, p.203-06, 1993.

IVANY, J.A. Effect of glyphosate application at different growth stages on quackgrass control. Canadian Journal of Plant Science, v.55, p.861-3, 1975. 
JEFFERY, L.; ENGLISH, J.R.; CONNELL, J. The effect of fall application of glyphosate on corn (Zea mays), soybean (Glycine max), and Johnsongrass (Sorghum halepense L.). Weed Science, v.29, p.190-5, 1981.

JORDAN, T.N. Effects of temperature and relative humidity on the toxicity of glyphosate to bermudagrass. Weed Science, v.25, p.448-51, 1977.

JORDAN, T.N. Effects of diluent volumes and surfactant on the phytoxicity of glyphosate to bermudagrass (Cynodon dactylon). Weed Science, v.29: p.79-83, 1981.

KELLS, J.J.; RIECK, C.E. Effects of illuminance and time of accumulation of glyphosate in Johnsongrass (Sorghum halepense). Weed Science, v.27, p.235-7, 1979.

KENT, L.M.; WILLS, G.D.; SHAW, D.R. Influence of ammonium sulfate, imazapyr, temperature, and relative humidity on the absorption and translocation of imazethapyr. Weed Science, v.39, p.412-6, 1991.

KIRKWOOD, R.C. Use and mode of action of adjuvants for herbicides: a review of some current work. Pesticide Science, v.38, p.93-102, 1993.

KNOCHE, M.; BUROVAK, M.J. Interaction of surfactant and leaf surface in glyphosate absorption. Weed Science, v.41, p.87-93, 1993.

MacISAAC, S.; PAUL, R.N.; DEVINE, M.D. A scanning electron microscope study of glyphosate deposits in relation to foliar uptake. Pesticide Science, v.31, p.53-64, 1991.

McALLISTER, R.C.; HADERLIE, L.C. Translocation of ${ }^{14} \mathrm{C}$-labelled photoassimilates in Canada thristle (Cirsium arvense). Weed Science, v.33, p.153-9, 1985.

MARTIN, J.T.; JUNIPER, B.E. The cuticles of plants. London: Edward Arnold Ltd., 1970. 347p. 
MARTIN, R.A.; EDGINTON, L.V. Comparative systemic translocation of several xenobiotics and sucrose. Pesticide Biochemical Physiology, v.16, p.87-96, 1981.

NALEWAJA, J.D. Behaviour, applicability and efficacy of non-surfactant adjuvants. In: INTERNATIONAL SYMPOSIUM ON ADJUVANTS FOR AGROCHEMICALS. 4, Melbourne, 1995. p.186-92. (FRI. Bulletin, 193).

NALEWAJA, J.D.; MATYSIAK, R. Salt antagonism of glyphosate. Weed Science, v.39, p.622-8, 1991.

NALEWAJA, J.D.; MATYSIAK, R. Especies differ in response to adjuvants with glyphosate. Weed Technology, v.6, p.561-6, 1992a.

NALEWAJA, J.D.; MATYSIAK, R. 2,4-D and salt combinations affect glyphosate activity. Weed Technology, v.6, p.322-7, $1992 \mathrm{~b}$.

NALEWAJA, J.D.; MATYSIAK, R. Influence of diammonium sulfate and other salts on glyphosate phytotoxicity. Pesticide Science, v.38, p.77-84, 1993.

NALEWAJA, J.D.; MATYSIAK, R.; FREEMAN, T.P. Spray droplet residual of glyphosate in various carries. Weed Science, v.40, p.576-89, 1992.

NALEWAJA, J.D.; MATYSIAK, R.; SZELEZNIAK, R. Sethoxydin response to spray carrier chemical properties and environment. Weed Technology, v.8, p.591-7, 1994.

O'SULLIVAN, P.A.; O'DONOVAN; HAMMAN, W.M. Influence of nonionic surfactants, ammonium sulfate, water quality and spray volume on phytotoxicity of glyphosate. Canadian Journal of Plant Science, v.61, p.391-400, 1981. 
PAVEZI, R.T. Controle da tiririca (Cyperus rotundus L.) através de métodos químico e mecânico. Piracicaba, 1988. 120p. Dissertação (Mestrado) - Escola Superior de Agricultura "Luiz de Queiroz", Universidade de São Paulo.

PEREIRA, W.; CRABTREE, G. Absorption and toxicity of glyphosate and oxyfluorfen in yellow nutsedge (Cyperus esculentus). Weed Science, v.34, p.923-9, 1986.

POOVAIAH, B.W.; LEOPOLD, A.C. Effect of organic salt on tissue permeability. Plant Physiology, v.58, p.182-5, 1976.

PUREA, N. A preliminary investigation into economising the use of glyphosate by using urea as a synergist on the Cook Island. Alafua Agricultural Bulletin, Rorotonga, v.10, n.1, p.9-11. Resumo 932. em Weed Abstract, v.35, n.3, p.104, 1986.

RICHARD, E.P.; SLIFE, F.W. In vivo and in vitro characterization of the foliar entry of glyphosate in hemp dogbane (Apocynum cannabinum). Weed Science, v.27, p.426-33, 1979.

RIECHERS, D.E.; WAX, L.M.; LIEBL, R.A.; BULLOCK, D.G. Surfactant effects on glyphosate efficacy. Weed Technology, v.9, p.281-5, 1995.

RIECHERS, D.E.; WAX, L.M.; LIEBL， R.A.; BUSH，D.R. Surfactant-increased glyphosate uptake into plasma membrana vesicles isolated from common lambsquarters leaves. Plant Physiology, v.105, p.1419-25, 1994.

RIOUX, R.J.; BANDEEN, J.D.; ANDERSON, G.W. Effect of growth stage on translocation of glyphosate in quackgrass. Canadian Journal of Plant Science, v.54, p.397-401, 1974

RODRIGUES, B.N.; ALMEIDA, F.S. de. Guia de herbicidas. 3.ed. Londrina, Edição dos autores, 1995. p.326-7. 
SALISBURY, C.D.; CHANDLER, J.M.; MERKLE, M.G. Ammonium sulfate enhancement of glyphosate and CS-0224 control of johnsongrass (Sorghum halepense). Weed Technology, v.5, p.18-21, 1991.

SANDBERG, C.L.; MEGGITT, W.F.; PENNER, D. Effect of diluent volume and calcium on glyphosate phytotoxicity. Weed Science, v.26, p.476-9, 1978.

SANDBERG, C.L.; MEGGITT, W.F.; PENNER, D. Absorption, translocation and metabolism of ${ }^{14} \mathrm{C}$-glyphosate in several weed species. Weed Research, v.20, p.195200,1980 .

SCHÖNHERR, J.; BUKOVAC, M.J. Preferencial polar pathways in the cuticle and their relationship to ectodesmata. Planta, v.109, p.73-93, 1970.

SHEA, P.J. \& TUPY, D.R. Reversal of cation-induced redution in glyphosate activity with EDTA. Weed Science, v.32, p.802-6, 1984.

SHERRICK, S.L.; HOLT, J.A.; HESS, F.D. Absorption and translocation of MON 0818 adjuvant in field bindweed (Convulvulus arvensis). Weed Science, v.34, p.817-23, 1986.

SHIEH, W.; GEIGER, D.R.; BUCZYNSKI, S.R. Distribution of imported glyphosate in quackgrass (Elytrigia repens $\mathrm{L}$. Nevski) rhizomes in relation to assimilate accumulation. Weed Science, v.41, p.7-11, 1993.

SPRANKLER, P.; MEGGITT, W.F.; PENNER, D. Absortion, action and translocation of glyphosate. Weed Science, v.23, p.235-40, 1975.

STAHLMAN, P.W.; PHILLIPS, W.M. Effects of water quality and spray volume on glyphosate phytotoxicity. Weed Science, v.27, p.38-41, 1979. 
STEEL, R.D.G.; TORRIE, H. Principles and procedures of statistics. 2.ed. NewYork: McGaw-Hill, 1981.

STEVENS, P.J.G.; BUKOVAC, M.J. Studies on octyl-phenoxy surfactants. Part 1: Effects of oxyethylene content on properties of potential relevance to foliar absortion. Pesticide Science, v.20, n.19-35, 1987.

STOCK, D.; HOLLOWAY, P.J. Possible mechanism for surfactant - induced foliar uptake of agrochemicals. Pesticide Science, v.38, p.165-77, 1993.

SUWUNNAMEK, U.; PARKER, C. Control of Cyperus rotundus L. with glyphosate: the influence of ammonium sulfate and other additives. Weed Research, v.15, p.13-9, 1975.

TARDIF, F.J.; LEROUX, G.D. Translocation of glyphosate and quizalofop and metabolism of quizalofop in quackgrass biotypes (Elytrigia repens). Weed Technology, v.5, p.525$31,1990$.

THELEN, K.D.; JACKSON, E.P.; PENNER, D. The basis of the hardwater antagonism of glyphosate activity Weed Science, v.43, p.541-8, 1995a.

THELEN, K.D.; JACKSON, E.P.; PENNER, D. Utility of nuclear magnetic resonance for determining the molecular influence of citric acid and an organosilicone adjuvant on glyphosate activity. Weed Science, v.43, p.566-71, $1995 \mathrm{~b}$.

TUCKER, T.A.; LANGELAND, K.A.; CORBIN, F.T. Absorption and translocation of ${ }^{14} \mathrm{C}$-Imazapyr and ${ }^{14} \mathrm{C}$-Glyphosate in alligator weed Alternanthera philoxeroides. Weed Technology, v.8, p.32-6, 1994. 
TURNER, D.J.; LOADER, M.P. Effect of ammonium sulfate and additives upon the phytotoxicity of glyphosate to Agropyron repens L. Beauv. Weed Research, v.20, p.139-46, 1980

TURNER, D.L.; LOADER, M.P. Effect of ammonium sulfate and related salts on the phytotoxicity of dichlorprop and other herbicides used for broadleaf weed control in cereal. Weed Research, v.24, p.67-77, 1984.

VICTORIA FILHO, R. Fatores que influenciam a absorção foliar dos herbicidas. Informe Agropecuário, v.11, n.129, p.31-7, 1985.

WADE, B.R.; RIECHERS, D.E.; LIEBL, R.A.; WAX, L.M. The plasma membrane as a barrier to herbicide penetration and site for adjuvant action. Pesticide Science, v.37, p.195-202, 1993.

WALLACE, R.W.; BELLINDER, R.R. Glyphosate absorption and translocation in rustinfected quackgrass (Elytrigia repens). Weed Science, v.43, p.1-6, 1995.

WESTRA, P.H.; WYSE, D.L.; COOK, E.F. Weevil (Notaris bimaculatus) feeding reduces effectiveness of glyphosate on quackgrass (Agropyron repens). Weed Science, v.29, p.540-7, 1981 .

WILSON, B.J.; NISHIMOTO, R.K. Ammonium sulfate enhancement of picloram absorption by detached leaves. Weed Science, v.23, p.297-301, 1975.

WYRILL, J.B.; BURNSIDE, O.C. Absorption, translocation and metabolism of 2,4-D and glyphosate in common milkweed and hemp dogbane. Weed Science, v.24, p.557-66, 1976.

WYRILL, J.B.; BURNSIDE, O.C. Glyphosate toxicity to common milkweed and hemp dogbane as influenced by surfactants. Weed Science, v.25, p.275-87, 1977. 
YAMADA, Y.; WITTWER, S.H.; BUKOVAC, M.J. Penetration of ions through isolated cuticles. Plant Physiology, n.39, p.28-32, 1964.

YORK, A.C.; JORDAN, D.L.; WILCUT, J.W. Effects of ammonium sulphate and BCH815085 on efficacy of sethoxydin. Weed Technology, v.4, p.76-80, 1990.

ZANDSTRA, B.H.; NISHIMOTO, R.K. Movement and activity of glyphosate in purple nutsedge. Weed Science, v.25, p.268-74, 1977. 